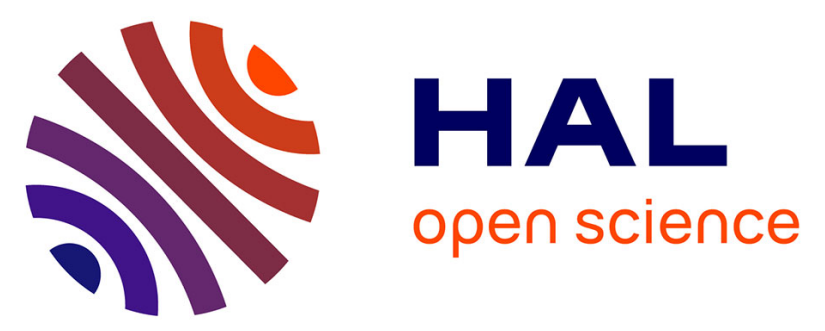

\title{
Geographic variation in stable isotopic and fatty acid composition of three families of anguilliform leptocephali and particulate organic matter (POM) in the western South Pacific
}

Camilla Liénart, Eric Feunteun, Michael J. Miller, Jun Aoyama, Jean-Michel Mortillaro, Cédric Hubas, Mari Kuroki, Shun Watanabe, Christine Dupuy, Alexandre Carpentier, et al.

\section{- To cite this version:}

Camilla Liénart, Eric Feunteun, Michael J. Miller, Jun Aoyama, Jean-Michel Mortillaro, et al.. Geographic variation in stable isotopic and fatty acid composition of three families of anguilliform leptocephali and particulate organic matter (POM) in the western South Pacific. Marine Ecology Progress Series, 2016, 544, pp.225-241. 10.3354/meps11575 . hal-01243513

\author{
HAL Id: hal-01243513 \\ https://hal.science/hal-01243513
}

Submitted on 15 Dec 2015

HAL is a multi-disciplinary open access archive for the deposit and dissemination of scientific research documents, whether they are published or not. The documents may come from teaching and research institutions in France or abroad, or from public or private research centers.
L'archive ouverte pluridisciplinaire HAL, est destinée au dépôt et à la diffusion de documents scientifiques de niveau recherche, publiés ou non, émanant des établissements d'enseignement et de recherche français ou étrangers, des laboratoires publics ou privés. 


\section{Geographic variation in stable isotopic and fatty acid composition} of three families of anguilliform leptocephali and particulate organic matter (POM) in the western South Pacific

\author{
Camilla Liénart $^{1 *}$, Eric Feunteun ${ }^{1,2}$, Michael J. Miller ${ }^{3,4}$, Jun Aoyama ${ }^{3}$, \\ Jean-Michel Mortillaro ${ }^{1}$, Cédric Hubas ${ }^{1}$, Mari Kuroki ${ }^{5}$, Shun Watanabe ${ }^{3,4}$, \\ Christine Dupuy ${ }^{6}$, Alexandre Carpentier ${ }^{7}$, Tsuguo Otake ${ }^{3,5}$, \\ Katsumi Tsukamoto ${ }^{3,4}$, and Tarik Meziane ${ }^{1}$
}
${ }^{1}$ Unité Mixte de Recherche 'Biologie des organismes et écosystèmes aquatiques' (BOREA, UMR 7208), Muséum national d'Histoire naturelle, Université Pierre et Marie Curie, Université de Caen Basse-Normandie, Centre National de la Recherche Scientifique, Institut de Recherche pour le Développement-207, Université des Antilles; CP53, 61 rue Buffon, 75005 Paris, France

${ }^{2}$ Muséum National d'Histoire Naturelle, Station Marine de Dinard, CRESCO, 38 rue du port Blanc, 35800 Dinard, France

${ }^{3}$ Atmosphere and Ocean Research Institute, The University of Tokyo, 5-1-5 Kashiwanoha, Kashiwa, Chiba, 277-8564, Japan

${ }^{4}$ Laboratory of Eel Science, Department of Marine Science and Resources, College of Bioresource Sciences, Nihon University 1866 Kameino, Fujisawa-shi, Kanagawa, 252-0880, Japan

${ }^{5}$ Department of Aquatic Bioscience, Graduate School of Agricultural and Life Sciences, The University of Tokyo, 1-1-1, Yayoi, Bunkyo, Tokyo 113-8657, Japan

${ }^{6}$ UMR 7266 LIENSs, Littoral Environnement et Société, 2, rue Olympe de Gouges 17000 La Rochelle, France

${ }^{7}$ EA 7316, Université de Rennes 1, 35042 Rennes Cedex
Corresponding Author: camilla.lienart@gmail.com

* UMR-CNRS 5805 EPOC, Environnements et Paléoenvironnements Océaniques et Continentaux, Université de Bordeaux, Station Marine d'Arcachon, 2 rue du Pr Jolyet, 33120, Arcachon cedex, France 
Running Heading: Variation in leptocephalus composition in western South Pacific. 
ABSTRACT: The feeding ecology of leptocephali has remained poorly understood because they apparently feed on particulate organic matter (POM), which varies in composition, and it is unclear which components of the POM they assimilate. The $\delta^{13} \mathrm{C}$ and $\delta^{15} \mathrm{~N}$ stable isotope (SI) and fatty acid (FA) compositions of 3 families of leptocephali and POM were compared in 3 latitudinal current zones of the western South Pacific. The $\delta^{15} \mathrm{~N}$ signatures of both leptocephali and POM overlapped, with both having their lowest values in the southern current zone. POM contained 38 FAs and was rich in saturated FAs (SFA) (16:0, 18:0, 14:0), while leptocephali contained $50 \mathrm{FAs}$, with high proportions of 16:0, and higher contributions of

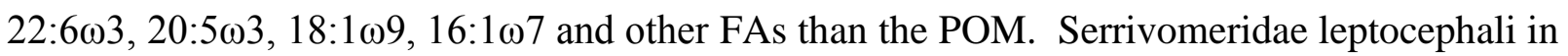
the north had higher $\delta^{15} \mathrm{~N}$ signatures and were also distinguished from Nemichthyidae and

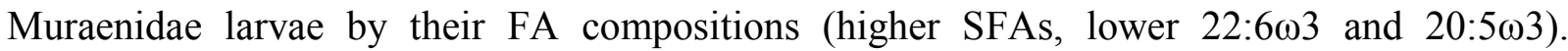
Although SI signatures of the Serrivomeridae larvae did not clearly vary with size, 16:0 and 18:0 FA proportions decreased with increasing larval size, and 22:6 $\omega 3$ and 16:1 107 increased in larger larvae. Correspondences between the latitudinal variations in nitrogen SI signatures and FA compositions of POM with those of leptocephali and the presence of FA markers of both autotrophic and heterotrophic organisms were consistent with leptocephali feeding on POM. POM can contain various materials from primary producers and heterotrophic microorganisms, but differences in the SI signatures and FA compositions in leptocephali remain to be explained through further research.

KEYWORDS: Leptocephali, fatty acids, stable isotopes, biomarkers, trophic ecology, oceanic currents.

\section{INTRODUCTION}

Leptocephali are the larvae of approximately 15 families of anguilliform fishes and their close relatives, which are widely distributed in the oceans from low-latitude temperate zones to tropical latitudes (Böhlke 1989, Miller \& Tsukamoto 2004; Miller 2009). They have highly laterally-compressed, transparent bodies and a unique physiology compared to other fish larvae (Pfeiler 1999, Bishop et al. 2000). All eel families except the Anguillidae are almost exclusively marine and live in habitats ranging from the meso- and bathy- pelagic zones (e.g., Nemichthyidae, Serrivomeridae) to coastal areas (e.g., Muraenidae) (Miller \& Tsukamoto 2004). All leptocephali however, are present together in the near the surface to $300 \mathrm{~m}$ depth zone of oceanic areas (Castonguay \& McCleave 1987, Miller 2009). Dependent on their taxa 
and adult habitats, the pelagic phase lasts for several months to more than a year before the larvae undergo metamorphosis into juveniles (Marui et al. 2001).

Despite their wide distributions and the extensive literature on their morphology (e.g., Böhlke 1989), the feeding ecology of leptocephali is still poorly resolved. During their larval feeding and growth period, leptocephali accumulate energy storage compounds such as lipids and glycosaminoglycans (GAG) in a gelatinous body matrix, which are then used for building new tissues during metamorphosis (Padrón et al. 1996, Pfeiler 1999, Pfeiler et al. 2002). A few studies have examined the gut contents of leptocephali and have observed materials that resemble particulate organic matter (POM) such as marine snow, discarded appendicularian houses or faecal pellets (Otake et al. 1993, Mochioka \& Iwamizu 1996, Miller et al. 2011). Carbon and nitrogen stable isotope studies of leptocephali indicate they feed at a low trophic level (Otake et al. 1993, Miyazaki et al. 2011, Feunteun et al. 2015), which was confirmed using amino acid nitrogen isotopes (Miller et al. 2013).

Other observations have suggested that leptocephali might also feed on microplanktonic organisms such as protozoans (Tanaka et al. 1995, Govoni 2010) and the DNA sequences of various organisms including gelatinous zooplankton have been detected in leptocephalus stomach contents (Riemann et al. 2010). Marine snow however, can be composed of multiple materials and/or organisms, due to both aggregation and colonization processes (Alldredge \& Silver 1988, Shanks \& Walters 1997, Kiørboe 2000). Therefore, the hypothesis that leptocephali feed on POM and assimilate some of the components of marine snow, including colonising microorganisms, appears most likely (Deibel et al. 2012, Miller et al. 2013, Feunteun et al. 2015). Differences in the isotopic compositions of leptocephali taxa have been detected and clear correspondences between POM signatures and expected enrichment values in leptocephali have not always been observed (Miyazaki et al. 2011, Feunteun et al. 2015). Thus, it is unclear if leptocephali feed on POM opportunistically or if there are selective differences in the types of POM consumed and/or the types of compounds assimilated from ingested POM between different taxa.

An important component of the POM and organisms that potentially contribute to the diet of leptocephali are lipids, but only a few studies have examined the lipid content of leptocephali (Padrón et al. 1996, Deibel et al. 2012). Lipids are important for marine organisms because they are their major metabolic energy reserves (Falk-Petersen et al. 2000, Lee et al. 2006) and play key roles in cell structure and metabolism (Dalsgaard et al. 2003). Fatty acids (FAs) are a specific class of lipids that are energy rich molecules (Dalsgaard et al. 
2003). Most consumers are unable to synthetize essential FAs (EFAs: 20:4 $\omega 6,20: 5 \omega 3$,

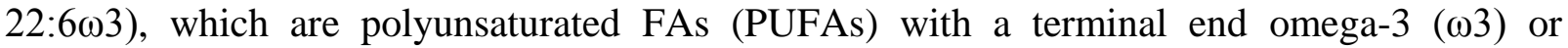
omega-6 $(\omega 6)$, due to their lack of specific enzymes and therefore they acquire these EFA molecules exclusively from the food they eat (Canuel et al. 1995, Styrishave \& Andersen 2000, Meziane et al. 2002, Dalsgaard et al. 2003).

Biochemical tracers such as FAs and stable isotope ratios (SI) are commonly used in trophic ecology studies because they provide information about the food sources that are assimilated by the organism over time (Pitt at al. 2009). SI ratios of carbon $\left({ }^{13} \mathrm{C}\right)$ and nitrogen $\left(\delta^{15} \mathrm{~N}\right)$ are used to evaluate the food sources of organisms (Fry \& Sherr 1984, Canuel et al. 1995) and to characterize organic matter transfer through food webs (Fry \& Sherr 1984, Canuel et al. 1995, Abrantes \& Sheaves 2009). FAs can be used as biomarkers of specific organisms (Meziane et al. 2007), or to determine the food sources exploited by consumer organisms (Meziane et al. 1997, Meziane \& Tsuchiya 2000, Mortillaro et al. 2015). They can also be used to follow organic matter transfer through food webs (Dalsgaard et al. 2003, Budge et al. 2006, Hall et al. 2006) and can provide information on larval ontogenetic changes (Plante et al. 2006).

This study used bulk SI and FA composition to provide information on the possible food sources of leptocephali and was specifically intended to investigate: (1) How leptocephali, belonging to three families, may assimilate POM and the associated microorganisms colonizing POM (protozoa, microalgae, bacteria, etc.) (2) Whether the diet of leptocephali changes with size and/or with latitude and/or current systems in the western South Pacific Ocean?

\section{MATERIALS AND METHODS}

\section{Study area and sample collection}

Leptocephali were collected in the western South Pacific (WSP) during Leg 1 of the KH-13-2 research cruise of the research vessel (R/V) Hakuho Maru from 4-24 February 2013. Thirty-four stations were sampled at every $2^{\circ}$ of latitude/longitude between $5^{\circ} \mathrm{S}-30^{\circ} \mathrm{S}$ and $165^{\circ} \mathrm{E}-175^{\circ} \mathrm{W}$, in the region that includes New Caledonia, Fiji and Samoa (Figure 1A). Leptocephali were collected using an Isaacs-Kidd midwater trawl (IKMT) with an $8.7 \mathrm{~m}^{2}$ mouth opening and $0.5 \mathrm{~mm}$ mesh. Sampling at each station was conducted following two strategies: during the night a step tow fished in the upper $120 \mathrm{~m}$ (10 min. steps at $120 \mathrm{~m}, 70 \mathrm{~m}$ and $50 \mathrm{~m}$ ), and during the day an oblique tow fished from the surface to $200 \mathrm{~m}$, with both types 
of tows taking less than 1 hour. Temperature, conductivity, depth (CTD) profiles were made at 21 of the stations to a depth of $500 \mathrm{~m}$.

Leptocephali from each IKMT sample were sorted fresh, measured and identified to the lowest possible taxonomic level according to Miller \& Tsukamoto (2004). A total of 538 leptocephali from 13 families were collected, but only the 3 most abundant families were analysed in this study. After identification and measurement, specimens to be used for SI and FA analyses were stored at $-80^{\circ} \mathrm{C}$. In this study, family is the only taxonomic level considered, and 101 leptocephali from the 3 most abundant families; Muraenidae $(n=27$; length 25.3-83.0 $\mathrm{mm}$, mean \pm S.D. $=50.1 \pm 13.4 \mathrm{~mm}$ ), Nemichthyidae ( $\mathrm{n}=28$; length $30.0-259.0 \mathrm{~mm}, 122.0 \pm 60.5$ ) and Serrivomeridae ( $\mathrm{n}=46$; length $9.2-62.0 \mathrm{~mm}, 28.4 \pm 14.4 \mathrm{~mm}$ ) were analysed for SI and FA composition (Figure 1). Five samples of the Serrivomeridae larvae samples consisted of 2 of the smallest larvae $(<10 \mathrm{~mm})$ pooled together to obtain enough tissue for analysis. Each leptocephalus specimen or pooled sample was used for both SI and FA analyses. Serrivomeridae larvae were used to examine differences in SI and FA composition in relation to leptocephalus size, because of the insufficient specimens of different sizes of Muraenidae and Nemichthyidae larvae, and the Serrivomeridae larvae were mostly from the same current zone.

Seawater samples were collected in triplicate at 13 stations (Figure 1A) in $12 \mathrm{~L}$ Niskin bottles attached to the CTD rosette multisampler at the depth of the chlorophyll maximum as measured by a fluorometer on the CTD were used for POM analyses. The depth of the chlorophyll maximum differed depending on the station, and was chosen because it is likely to have high concentrations of particulate material that may be suitable for feeding by leptocephali. No POM was sampled at the first CTD station in the southwest due to its proximity to the start of the cruise. POM was collected by filtering each $12 \mathrm{~L}$ of seawater sample through separate pre-combusted glass fibre filters (GF/F, $47 \mathrm{~mm}$ diameter, $0.7 \mu \mathrm{m}$ mesh). Large organisms such as copepods were removed manually and filters were immediately stored frozen at $-80^{\circ} \mathrm{C}$ until analysed.

\section{Stable isotopes analysis}

All samples were lyophilised before analysis. GF/F filters were fumigated with $10 \%$ $\mathrm{HCl}$ for $4 \mathrm{~h}$ to remove inorganic carbon (Lorrain et al. 2003). Leptocephali samples were weighed. Carbon $\left({ }^{13} \mathrm{C} /{ }^{12} \mathrm{C}\right)$ and nitrogen $\left({ }^{15} \mathrm{~N} /{ }^{14} \mathrm{~N}\right)$ SI analysis were performed by the UC Davis Stable Isotope Facility (Department of Plant Sciences, University of California at Davis, 
Davis, California) using a PDZ Europa ANCA-GSL elemental analyser for leptocephali analysis (half body, excluding the head region except for the smallest larvae) and an Elementar Vario EL Cube or Micro Cube elemental analyser (Elementar Analysensysteme GmbH, Hanau, Germany) for the GF/F filter POM samples (half filter). Each elemental analyser was interfaced to a PDZ Europa 20-20 isotope ratio mass spectrometer (Sercon Ltd., Cheshire, UK). Isotopic data are reported using standard delta notation $\left(\delta^{13} \mathrm{C}\right.$ or $\left.\delta^{15} \mathrm{~N}\right)$, defined as parts per thousand deviation (\%) from an international standard (Vienna Peedee belemnite for $\delta^{13} \mathrm{C}$ and atmospheric $\mathrm{N}_{2}$ for $\delta^{15} \mathrm{~N}$ ) as defined by the equation:

$$
\delta^{13} \mathrm{C} \text { or } \delta^{15} \mathrm{~N}=\left[\left(R_{\text {sample }} / R_{\text {standard }}\right)-1\right] \times 1000
$$

Where $R={ }^{15} \mathrm{~N} /{ }^{14} \mathrm{~N}$ or ${ }^{13} \mathrm{C} /{ }^{12} \mathrm{C}$ of the sample or standard (Peterson \& Fry 1987). The analytical precision (standard deviation for repeated measurements of internal standards) was $\pm 0.2 \%$ and $\pm 0.3 \%$ for $\delta^{13} \mathrm{C}$ and $\delta^{15} \mathrm{~N}$, respectively. All mean values of SI and FA data are expressed as mean \pm standard deviation (S.D.).

\section{Fatty acid analysis}

Lipids were extracted following Meziane et al. (2007). Briefly, lipid samples (half bodies or filters) were extracted twice with a mixture of distilled water, $\mathrm{MeOH}$ and $\mathrm{CHCl}_{3}$ $(1: 2: 1, \mathrm{v}: \mathrm{v}: \mathrm{v})$. Saponification and methylation were performed successively under reflux according to Meziane \& Tsuchiya (2000). Saponification was achieved using a $2 \mathrm{M}$ $\mathrm{NaOH}: \mathrm{MeOH}$ solution $(1: 2, \mathrm{v}: \mathrm{v})$ and methylation with $1 \mathrm{ml}$ of $14 \% \mathrm{BF}_{3}-\mathrm{MeOH}$. The fatty acid methyl esters (FAMEs) were separated and quantified by Gas Chromatography (Varian CP-3800) using a flame ionisation detector at the National Museum of Natural History (MNHN-Paris, Resaqua Laboratory). Separation was performed with an Agilent J\&W GC VF-WAXms column (30 m x $0.25 \mathrm{~mm}$ i.d.; $0.25 \mu \mathrm{m}$ film thickness) with $\mathrm{He}$ as carrier gas. Most of FAs peaks were identified by comparing their retention times with those of known standards (Supelco $^{\mathrm{TM}} 37$ FAME mix; Sigma-Aldrich ${ }^{\circledR}$ ) and confirmed with a GC-mass spectrometer (Varian 450-GC 220-Ion Trap MS; He as carrier gas). FAs are designated as $\mathrm{X}: \mathrm{Y} \omega \mathrm{Z}$, where $\mathrm{X}$ is number of carbon atoms, $\mathrm{Y}$ is number of double bonds and $\mathrm{Z}$ is the position of the ultimate double bond with respect to the terminal methyl group. The concentration of each FA was calculated using 23:0 as an internal standard according to Schomburg (1987): $\mathrm{C}_{\mathrm{FA}}=\mathrm{A}_{S} / \mathrm{A}_{\mathrm{IS}} \times \mathrm{C}_{\mathrm{IS}} / \mathrm{W}_{\mathrm{S}}$, where $\mathrm{A}_{\mathrm{S}}$ is the peak area of the $\mathrm{FA}, \mathrm{A}_{\mathrm{IS}}$ the peak 
area of the internal standard, $\mathrm{C}_{\mathrm{IS}}$ the concentration of the standard and $\mathrm{W}_{\mathrm{S}}$ the dry weight of sample.

\section{Latitudinal regions of the study area}

The study area was located within the northwestern part of the WSP subtropical gyre (Qiu \& Chen 2004). The water temperature in this region decreases from the north to south (Miller et al. 2006) and during the survey it ranged from $29^{\circ} \mathrm{C}$ (surface) and $21-23^{\circ} \mathrm{C}(200 \mathrm{~m}$ ) at northern stations $\left(8^{\circ} \mathrm{N}\right)$ to $25^{\circ} \mathrm{C}$ and $18^{\circ} \mathrm{C}$ respectively in the south $\left(24^{\circ} \mathrm{S}\right)$. This region includes 3 main surface currents at different latitudes, which are the westward South Equatorial Current (SEC, Equator to $20^{\circ} \mathrm{S}$ ), the narrow eastward South Equatorial Countercurrent (SECC) at 5 to $10^{\circ} \mathrm{S}$ (between two branches of the SEC), and the eastward South Tropical Countercurrent (STCC) at latitudes south of Fiji and north of New Zealand (Qiu \& Chen 2004; Ganachaud et al. 2014). The SECC was present north of $10^{\circ} \mathrm{S}$ according to ADCP observations made during the cruise, with mixed westward flow at central latitudes and mixed eastward flow in the south (Otake et al. unpubl. cruise report). The assemblages of leptocephali vary latitudinally in this region, with Serrivomeridae larvae being most abundant in the north, species such as Muraenidae being abundant at central latitudes, and Nemichthyidae being more equally distributed across latitudes (Miller et al. 2006) as they were during the present survey (Figure 1B-D). According to the general pattern of currents, the cruise stations were separated into 3 latitudinal zones for analyses of SI and FA compositions of leptocephali and POM, which generally correspond with the SECC, SEC, and STCC current systems (Figure 1B).

\section{Data analysis}

All SI and FA data are expressed as mean values \pm standard deviation (S.D.). Prior to statistical comparison, data were first evaluated for homocedasticity (Bartlett test) and normalality of distribution (Shapiro-Wilk test), which were not attained in most cases. Therefore, non-parametric Kruskal-Wallis (KW) tests were used to compare FA and SI group values, followed by pairwise comparisons with Mann-Whitney Wilcoxon (MWW) tests and Bonferroni correction to correct significance thresholds. When the sample size in a current zone was too low, only KW tests were used.

All FAs were used in the analyses and no transformations were performed on the dataset to prevent excessive weighting of low proportion FAs. Data matrices (\% TFA per 
sample) were used to create triangular dissimilarity matrices with the Bray-Curtis dissimilarity coefficient, followed by non-metric multidimensional scaling (n-MDS). Stress values $<0.2$ were considered robust (Clarke 1993). Groups used as factors for the analysis were family (Muraenidae, Nemichthyidae, Serrivomeridae) and size groups ( $\leq 10.0,10.1-20.0,20.1-40.0$, 40.1-60.0 mm, Serrivomeridae only), as well as current zones (SEC, SEC, STCC) for both leptocephali and POM. Differences in FAs composition among groups was statistically tested using separate one-way analysis of similarity (ANOSIM) computed after 5000 permutations. Average dissimilarity (AD) between groups was determined by SIMilarity of PERcentage (SIMPER) analysis (PRIMER ${ }^{\circledR} 5$ software module) was used to identify which fatty acids determine the observed differences within or between groups.

Multivariate analyses were performed with PRIMER ${ }^{\circledR} 5$ software (Clarke \& Warwick, 2001) and univariate tests using R software (R development Core Team 2014, Vegan package, Oksanen et al. 2014). For all univariate tests, the probability $\alpha$ was set at 0.05 .

\section{RESULTS}

\section{Isotopic and fatty acids composition of Particulate organic matter and leptocephali}

Particulate organic matter (POM). SI values of POM (Figure 2) ranged from -27.8\%o to $-25.0 \%$ for $\delta^{13} \mathrm{C}\left(\right.$ mean \pm S.D. $=-26.6 \pm 0.7 \%$ ) and from $2.5 \%$ o to $10 \%$ o for $\delta^{15} \mathrm{~N}(6.1 \pm 2.3 \%$ ) (Table 1). A total of 38 FAs were identified in the POM (Table 1). Average saturated fatty acid (SFAs) contribution to POM was $75.2 \pm 4.6 \%$ of total FAs, with 16:0 showing the highest contribution $(35.9 \pm 2.3 \%)$. The main monounsaturated fatty acids (MUFAs) were 18:1 $\omega 9$ $(5.3 \pm 1.1 \%)$ and $16: 1 \omega 7(4.4 \pm 0.9 \%)$. All relative contributions of polyunsaturated fatty acids (PUFAs) were low with maximum values of $1.7 \pm 0.4 \%$ for $16: 2 \omega 4,1.7 \pm 0.8 \%$ for $22: 6 \omega 3$ and $1.7 \pm 0.5 \%$ for $18: 4 \omega 3$. Similarly, EFAs $20: 5 \omega 3$ and $20: 4 \omega 6$ had low contributions to TFAs (about or $\leq 1 \%$ ). Contributions of branched-chain fatty acid (BrFAs) were $2.4 \pm 0.4 \%$ of TFAs.

Leptocephali. For the 3 families of leptocephali (Figure 2), $\delta^{13} \mathrm{C}$ stable isotope values ranged from $-23.1 \%$ o to $-18.8 \%$ and from $0.7 \%$ o to $14.5 \%$ for $\delta^{15} \mathrm{~N}$ (Table 1 ). There was a significant difference in $\delta^{13} \mathrm{C}$ composition between Serrivomeridae $(-21.0 \pm 0.8 \%$ o $)$ and Nemichthyidae (-19.9 $\pm 0.8 \%$ ) leptocephali (KW: $p<0.001$; followed by MWW: $p<0.001$ ). $\delta^{15} \mathrm{~N}$ signatures were significantly different among each of the 3 families (KW: $p<0.001$; MWW: $p<0.01$ ) with an average $\delta^{15} \mathrm{~N}$ of $4.7 \pm 3.3 \%$ for Nemichthyidae, $6.7 \pm 2.7 \%$ for Muraenidae and $10.9 \pm 1.9 \%$ for Serrivomeridae. 
A total of 50 FAs was identified in leptocephali (Table 1), with a large contribution of SFAs, MUFAs, and PUFAs to TFAs. The same 6 FAs $(16: 0,16: 1 \omega 7,18: 0,18: 1 \omega 9,20: 5 \omega 3$ and 22:603) were most abundant in all 3 families, with all the other FAs each contributing less than about $4 \%$ to the TFAs. Muraenidae had higher levels of FAs by weight $\left(11.7 \pm 7.4 \mathrm{mg} \mathrm{g}^{-1}\right)$ than Nemichthyidae $\left(5.2 \pm 2.5 \mathrm{mg} \mathrm{g}^{-1}\right)$ and Serrivomeridae $\left(5.4 \pm 4.0 \mathrm{mg} \mathrm{g}^{-1}\right)$.

The 3 families also showed differences regarding their FAs compositions (ANOSIM: $p<0.001$ ), with Muraenidae showing no overlap with the Serrivomeridae and Nemichthyidae, which overlapped to some degree in the n-MDS plot (Figure 3). FAs profiles of leptocephali exhibited average dissimilarity values (AD; SIMPER analysis) that were more similar between Muraenidae and Serrivomeridae (16.6\%) than between Muraenidae and Nemichthyidae (14.3\%) and between Nemichthyidae and Serrivomeridae (14.6\%). The observed differences

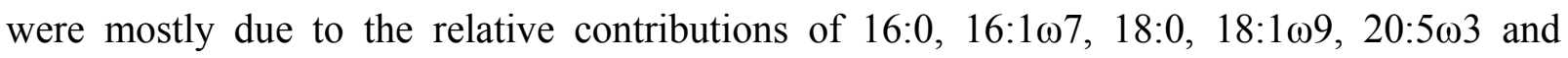
22:6 63 to TFAs (Table 1). SFAs contributed a higher proportion of TFAs in Serrivomeridae leptocephali (44.8 $\pm 7.5 \%$ ) than PUFAs $(33.8 \pm 5.7 \%)$, whereas the PUFAs contribution was slightly higher in Muraenidae and Nemichthyidae (42.3 $\pm 3.7 \%$ and $39.4 \pm 4.2 \%$, respectively) than SFAs contribution (38.5 $\pm 3.7 \%$ and $37.4 \pm 4.2 \%$, respectively) (Figure $4 \mathrm{~A}, \mathrm{~B}$ ). The total $\omega 3$ FAs contribution were significantly different (KW: $p<0.001$; MWW: $p<0.05$ ) for the 3 families, ranging from $23.7 \pm 5.5 \%$ for Serrivomeridae to $32.5 \pm 3.8 \%$ for Muraenidae (Figure 4C). BrFAs contributed less than $1 \%$ of TFAs, but differed significantly in their contribution to TFAs (KW: $p<0.001$; MWW: $p<0.001$ ) between Muraenidae $(0.5 \pm 0.1 \%)$ and the other families (Nemichthyidae: $0.8 \pm 0.1 \%$ and Serrivomeridae: $0.9 \pm 0.2 \%$ ) (Figure 4D).

Fatty acid trophic markers (FATMs) of the leptocephali included two predominant 16:0 and 22:6 63 FAs, which contributed on average $40 \%$ of the TFAs (Table 1). Proportions of the PUFAs $20: 5 \omega 3$ and $22: 6 \omega 3$ were lower for Serrivomeridae $(5.1 \pm 2.1 \%$ and $14.8 \pm 3.2 \%$, respectively) than for the two other families (KW $p<0.001$; MWW: $p<0.001$ ). Muraenidae had the highest percentage of 22:603 of the 3 families. The contribution of 18:109 to TFAs was lower for Muraenidae (5.8 $\pm 0.9 \%$; KW: $p<0.001$; MWW: $p<0.001)$ than Nemichthyidae and Serrivomeridae $(8.3 \pm 1.7 \%$ and $8.8 \pm 1.3 \%$, respectively).

\section{FA compositions and SI signatures of Serrivomeridae size groups}

The 4 size groups of Serrivomeridae leptocephali were compared for their FAs and SI signatures. No significant differences were found between size groups for $\delta^{15} \mathrm{~N}$ (Table 2) and 
$309 \quad \delta^{13} \mathrm{C}$ values were only significantly different for $\leq 10 \mathrm{~mm}$ larvae $(-19.9 \pm 0.6 \%$ ) and $40-60 \mathrm{~mm}$ larvae $(-21.4 \pm 0.5 \%$ ) (KW: $p<0.01$; MWW: $p<0.05)$.

The FA compositions of the Serrivomeridae leptocephali showed various percentage changes with increasing size, with SFAs and BrFAs tending to decrease, and MUFAs and PUFAs tending to increase with increasing leptocephali size (Table 2). The total weight of FA in the body of the leptocephali tended to decrease only slightly from the smallest to largest size classes $\left(5.8\right.$ to $4.4 \mathrm{mg} \mathrm{g}^{-1}$ ) but differences were not significant. The $40-60 \mathrm{~mm}$ and $\leq 10 \mathrm{~mm}$ sizes classes were significantly different in FA composition (ANOSIM: $p<0.05$; n-MDS), Figure 5) with an $\mathrm{AD}$ of $23.2 \%$. The SFAs contribution to $\leq 10 \mathrm{~mm}$ larvae was higher $(56.7 \pm 0.9 \%)$ and PUFAs contribution was lower $(25.2 \pm 0.6 \%)$ than in $40-60 \mathrm{~mm}$ larvae (37.1 $\pm 0.3 \%$ for SFAs and $39.0 \pm 0.4 \%$ for PUFAs) mainly due to the contribution of the SFAs

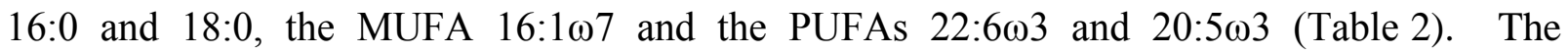
contribution of $\omega 3$ FAs increased with size, from $16.4 \pm 1.0 \%$ for $\leq 10 \mathrm{~mm}$ to $30.0 \pm 0.7 \%$ for 40 $60 \mathrm{~mm}$ larvae.

\section{POM and leptocephali SI signatures in current zones}

The POM exhibited variation in $\delta^{15} \mathrm{~N}$ values, which ranged from $7.7 \pm 2.3 \%$ in the SECC in the north, to $4.1 \pm 1.0 \%$ in the STCC in the southeast (Table 3), although the SEC values overlapped with those of the other zones (Figure $6 \mathrm{D}$ ). The $\delta^{13} \mathrm{C}$ values showed less variation with mean values that ranged from $-27.0 \pm 0.2 \%$ to $-26.2 \pm 0.9 \%$, but some of the SECC values were lower (Figure 6D). When FA compositions of POM were separated according to the 3 current zones, samples from the SECC $\left(5-15^{\circ} \mathrm{S}\right)$ were significantly different (ANOSIM: $p<0.05)$ from those of both the SEC $\left(15-20^{\circ} \mathrm{S}\right)$ and STCC $\left(20-30^{\circ} \mathrm{S}\right)$ with an AD of $12.5 \%$ between the SECC and SEC, and 13.2\% between SECC and STCC. These differences mostly resulted from variations in the proportions of the SFAs 18:0, 16:0 and 14:0

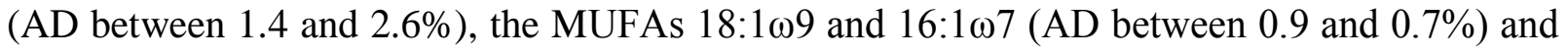

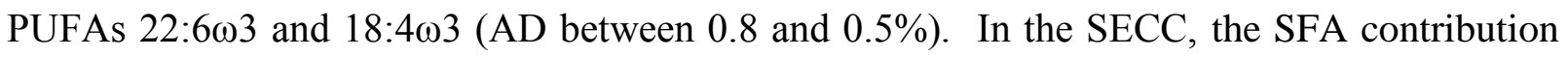
was higher $(78.8 \pm 3.9 \%)$ and MUFA and PUFA contributions lower $(11.7 \pm 2.9 \%$ and $7.1 \pm 1.4 \%)$ than in the other zones (Table 3).

Leptocephali also showed differences in isotopic signatures between the 3 current zones, with $\delta^{15} \mathrm{~N}$ values being different ( $\mathrm{KW}$ and MWW: $p<0.05$ ). Some separation of the $\delta^{15} \mathrm{~N}$ signatures in the 3 zones was also seen within families, except there was only one Serrivomeridae larva analysed from the STCC (Figure 6A-C). For Serrivomeridae 
342 leptocephali there was no significant difference in $\delta^{13} \mathrm{C}$ values between larvae caught in the different current zones, whereas $\delta^{15} \mathrm{~N}$ signatures were different between larvae from the SECC and SEC (t-test: $p<0.05$ ) (Figure 6C). Muraenidae from the SEC and SECC had different in both their $\delta^{13} \mathrm{C}$ and $\delta^{15} \mathrm{~N}$ values (KW and MWW: $p<0.05$ ) (Figure 6B). There were also differences in the $\delta^{13} \mathrm{C}$ and $\delta^{15} \mathrm{~N}$ signatures of Nemichthyidae found in the STCC and those in the SECC and SEC, respectively (KW and MWW: $p<0.05$ ) (Figure 6A). FA profiles for the leptocephali caught in the three different currents were not significantly different (KW and MWW: $p>0.1)$.

\section{DISCUSSION}

\section{FA and SI signatures of leptocephali and POM}

This study examined the variation of the FA profiles and SI signatures of 3 families of leptocephali and their likely food source of POM. Samples were collected across a wide range of latitudes and longitudes of the WSP. Previous studies in the western North Pacific (Miyazaki et al. 2011) and western Indian Ocean (Feunteun et al. 2015) analysed leptocephali and POM from much more limited areas of the ocean.

The chemical composition of the different taxa of leptocephali is generally comparable (Pfeiler 1999, Bishop et al. 2000) as confirmed by the FA profiles of the 3 families of leptocephali studied in the WSP that show many similarities. There were however, also some differences. The Nemichthyidae, Muraenidae, and Serrivomeridae larvae had the same number of major FAs and categories of FAs markers showed similar proportions. Deibel et al. (2012) also found similar FA compositions for 6 other taxa of leptocephali (Congridae, Muraenesocidae, Ophichthidae) from coastal, shelf or deep slope habitats off northwest Australia. However, despite these overall similarities, the present study found small but significant differences between the FA profiles of Muraenidae larvae and those of Nemichthyidae and Serrivomeridae. The similarities in FAs compositions of the 3 families were largely due to the FAs that were present in large proportions: 16:0, 18:0, 22:6 $\omega 3,20: 5 \omega 3$,

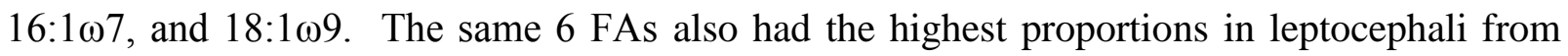
northwestern Australia (Deibel et al. 2012).

SFAs 16:0 and 18:0 (mean $24 \%$ and 8\% of TFAs in all 3 families of leptocephali) are the most abundant FAs in nature as they are products of lipogenesis in all organisms (Dewick 1997). Similarly, $\omega 3$ FAs are abundant in marine zooplankton (Lee et al. 2006) and fish larvae (Grote et al. 2011), as they were in the leptocephali, where they represented 24 to $33 \%$ of total 


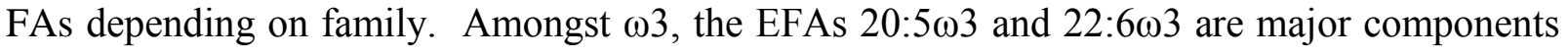
of cell membrane phospholipids (Sargent et al. 1993) and are also important for larval growth and development (Sargent et al. 1993, Furuita et al. 2006, Grote et al. 2011). Marine consumers however, cannot synthetize essential $\omega 3$ and $\omega 6$ PUFAs (Dalsgaard et al. 2003, Lee et al. 2006, Kattner et al. 2007) so they need to obtain them through feeding (Canuel et al. 1995, Styrishave \& Andersen 2000, Meziane et al. 2002). Thus, high proportions of $\omega 3$ and $\omega 6$ in leptocephali suggest that leptocephali feed on material containing or originating from autotrophic organisms or primary consumers in which $\omega 3$ and $\omega 6$ are abundantly present (Scott et al. 2002, Dalsgaard et al. 2003, Lee et al. 2006). There is also the possibility that leptocephali, as do some heterotrophic organisms (Dalsgaard et al. 2003, Canuel et al. 1995), synthesize these FAs from a precursor such as 18:1 19 . This MUFA is abundant in leptocephali (mean of $7.6 \pm 1.6 \%$ for the 3 families combined in this study, and $6.4 \pm 1.3 \%$ in Deibel et al. 2012) and can be obtained from feeding on zooplankton or other heterotrophic sources in pelagic food webs (Dalsgaard et al. 2003, Lee et al. 2006).

In this study, POM was characterized by a strong contribution of SFAs ( $75 \%$ of TFAs) and a low contribution of $\omega 3(\sim 5 \%)$, MUFAs $(\sim 13 \%)$ and PUFAs $(\sim 9 \%)$, which typically indicates a low nutritional quality for the bulk organic matter, as suggested by other studies in diverse aquatic systems (e.g., North Sea, Boon \& Duineveld 1996; Amazon River, Mortillaro

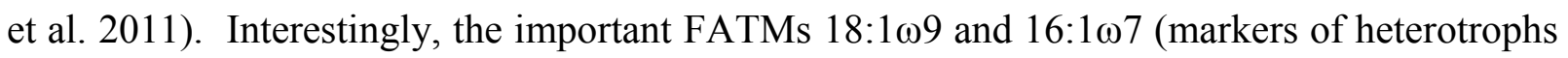
and autotrophic microplankton, respectively) were the main unsaturated FAs that contributed to the TFAs of POM ( $\sim 5$ and $4 \%$, respectively). Also, BrFA markers made a low contribution to TFAs $(\sim 2 \%)$ in POM. Most of these FATMs are typically biosynthesized in large amounts by bacteria (Kaneda 1991, Ederington et al. 1995, Meziane \& Tsuchiya 2000) and because decaying bulk POM is rapidly colonised by bacteria (Skerratt et al. 1995, Najdek et al. 2002), it would be expected to be rich in these BrFAs. Thus, the FA composition may indicate that the POM sampled within the chlorophyll maximum layer during this study is likely to be composed of a large non-living POM fraction (detritus, faecal pellets, etc.) with a low bacterial influence and to a lesser extent of living organic material (autotrophic and heterotrophic microplankton) that leptocephali would preferentially assimilate.

The diet of an organism can usually be examined by assuming a mean isotopic trophic enrichment of 1\% in $\delta^{13} \mathrm{C}$ (DeNiro \& Epstein 1978, Rau et al. 1983) and of 3.4\% in $\delta^{15} \mathrm{~N}$ (DeNiro \& Epstein 1981, Minagawa \& Wada 1984) from food source to consumer. The $\delta^{15} \mathrm{~N}$ values of POM (2.5 to $12 \%$ ) and leptocephali $(0.5$ to $13 \%$ ) in the present study heavily 
overlapped, so no clear trophic enrichment between $\delta^{15} \mathrm{~N}$ signatures of POM and leptocephali was evident, except perhaps for Serrivomeridae. One explanation for this is that there could be a mismatch between the POM sampled on the filters and the types of POM that leptocephali consume and what they assimilate from this, as mentioned above and described further below. A similar result was also described by Otake et al. (1993), who found that the $\delta^{15} \mathrm{~N}$ signature of Congridae leptocephali (Conger myriaster) overlap with that of POM ( 11-13\%). A wide range of POM $\delta^{15} \mathrm{~N}$ values overlapping with those of leptocephali was also seen in studies in the western North Pacific (Miyazki et al. 2011) and western Indian Ocean (Feunteun et al. 2015). Other studies examining geographic variations in SI signatures of POM and organisms found similarly high values of $\delta^{15} \mathrm{~N}$ for POM (Waite et al. 2007, Lorrain et al. 2015). This is presumably a result of regional variations that occur globally in the $\delta^{15} \mathrm{~N}$ values of primary producers that contribute to POM, with some areas such as parts of the South Pacific likely having higher values than other regions of the world (Somes et al. 2010). The $\delta^{13} \mathrm{C}$ gap of about $7 \%$ between mean values (2\% gap for closest values) of POM and leptocephali is also clearly larger than the expected 1\%o gap if leptocephali were consuming POM within the chlorophyll maximum and assimilating all of it. The values of $\delta^{13} \mathrm{C}$ of the POM we collected within the chlorophyll maximum (about -25 to $-27 \%$ ) were lower than those usually reported for oceanic environments (e.g. Waite et al. 2007, Hwang et al. 2009, Miyazki et al. 2011). However, values of $\delta^{13} \mathrm{C}$ of bulk POM as low as -25 to $-29 \%$ have been reported at similar depths in several offshore areas (Jeffrey et al. 1983, Durffel et al. 2003, Feunteun et al. 2015, Soares et al 2015). These low $\delta^{13} \mathrm{C}$ bulk POM values are measured within or just below the depth of the chlorophyll maximum and this may be a common pattern in the open ocean (Jeffrey et al. 1983, Durffel et al. 1998, Hwang et al. 2009, Close et al. 2014). Moreover, POM is considered to be organic material that usually forms bigger particles commonly called "marine snow" that contains various living organisms (Alldredge \& Silver 1988, Shanks \& Walters, 1997, Kiørboe, 2000). Therefore, bulk POM composition in the open ocean likely depends on plankton communities but also on the non-living degraded part of the organic matter as well as bacterial communities. Isotopic fractionation and thus the signature of the bulk POM can differ due to variations in physiological processes between phytoplanktonic groups (metabolic ${ }^{13} \mathrm{C}$ enrichment, C-fixation) that are related to cell size, physiology and growth rate (Goericke \& Fry 1994, Popp et al. 1998). POM with widely varying $\delta^{13} \mathrm{C}$ and $\delta^{15} \mathrm{~N}$ signatures can be found at different depths (Jeffrey et al. 1983, Waite et al. 2007, Miyazki et al. 2011, Feunteun et al. 2015), so our POM isotopic values may be related to the specific 
signatures within the chlorophyll maximum, which is not targeted in studies that only sample at particular depths. Or they could be partly related to aspects of the biological communities in our study area, which have not yet been studied. These factors might explain the large range of values in carbon and nitrogen signatures of POM in the WSP.

It is also possible that leptocephali do not feed exclusively within the chlorophyll maximum or consume every type of POM. It is more likely that leptocephali select specific types of POM particles to eat, such as some types of marine snow or the appendicularian houses that have been directly observed in the intestines of leptocephali (Mochioka and Iwamizu 1996, Miller et al. 2011). In addition, some materials such as zooplankton faecal pellets observed in gut contents (Otake et al. 1993, Miller et al. 2011) are unlikely to be digested. Further differences between the SI signatures of the POM sample collected on a filter and those that leptocephali consume and assimilate might be related to the transparent exopolymer particles (i.e. TEP; Passow 2002) produced by microorganisms (phytoplankton, bacteria) that aggregate within POM. TEPs are mainly composed of carbohydrate molecules that aggregate into marine snow (Holloway and Cowen 1997, Skoog et al. 2008, Engel et al. 2012) and are at the interface between dissolved and particulate organic carbon (Passow 2002). Therefore, a significant fraction of TEP is likely not retained on the GF/F filters used to collect POM from the water samples, leading to these compounds being only partially included in POM carbon measurements; whereas they would have been present in the POM materials assimilated by leptocephali. In addition, carbohydrates are molecules having no nitrogen, only the $\delta^{13} \mathrm{C}$ signature of these compounds would be reflected in leptocephali if they were assimilated (Feunteun et al. 2015). Also, leptocephali have a long larval duration, so as previous studies have pointed out, larger larvae could be transported into collection areas after originating from other areas where they have fed on POM with different isotopic signatures (Myazaki et al. 2011, Feunteun et al. 2015).

\section{Feeding ecology of leptocephali}

Considering the various possible factors discussed above, the SI and FA analyses of this study may still be generally consistent with the hypothesis that leptocephali feed on POM, which has been indicated by direct observations of their gut contents (Otake et al. 1993, Miller et al. 2011) and an analysis of their trophic position (Miller et al. 2013). The observational studies of the gut contents of leptocephali that have found POM components such as amorphous materials, appendicularian and other zooplankton fecal pellets, and discarded 
appendicularian houses (Otake et al. 1993, Mochioka \& Iwamizu 1996, Miller et al. 2011), provide direct evidence of POM consumption by a variety of eel larvae taxa. Also, Feunteun et al. (2015) characterised SI signatures of many taxa of zooplankton along with 12 taxa of leptocephali and POM and did not find evidence of leptocephali feeding on zooplankton. However, as in previous SI studies (Miyazaki et al. 2011, Feunteun et al. 2015) it remains unclear what types and components of POM are used by various taxa of leptocephali, and methodological issues related to the filtration and analysis of POM may make it difficult to see clear linkages using SI analyses.

The FATM compositions determined in the present study and those of Deibel et al. (2012) indicate that leptocephali obtain their nutrition from various sources that include both

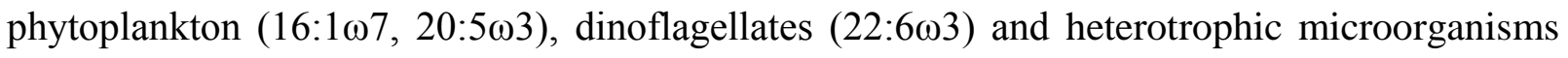

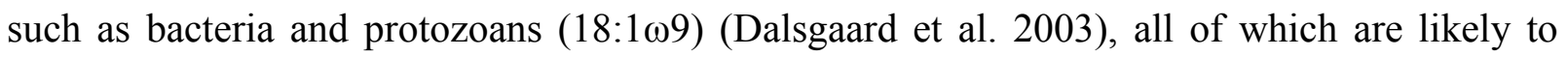
contribute to POM composition (Alldredge \& Silver 1988, Shanks \& Walters, 1997, Kiørboe, 2000). As explained above and also suggested in other studies (Dalsgaard et al. 2003, Pitt el al. 2009), the composition of the food contents in the intestines of leptocephali could be different from what they assimilate from ingested food. Our FA results suggest that it is the materials from living organisms associated with POM that are mainly assimilated by leptocephali (e.g. FATM of autotrophic and heterotrophic organisms). Indeed, Muraenidae larvae were rich in PUFAs and $\omega 3$ meaning even they feed on FA poor food source, they are able to preferentially assimilate and store FAs-rich components of the POM. Conversely, Serrivomeridae larvae had the highest SFA and lowest PUFAs and $\omega 3$ proportions, which suggests that they may feed on POM opportunistically, with no selective assimilation or FA storage.

\section{FA and SI composition of Serrivomeridae size classes}

Although no major differences were found in the isotopic compositions of the 4 size classes of Serrivomeridae leptocephali, clear changes in their FA composition were detected. The only significant SI differences were that $\delta^{13} \mathrm{C}$ values differed between the largest (-21.4\%o) and smallest (-19.9\%o) size classes, but no significant differences were found in $\delta 15 \mathrm{~N}$ values. In contrast, all the major categories of FAs showed at least minor changes with size, either increasing MUFA and PUFA or decreasing SFA contributions to TFAs.

The dynamic nature of lipid metabolism and the influence of dietary lipids when larvae first feed can cause FA composition shifts during ontogeny (Wiegand 1996, Rainuzzo et al. 1997, Plante et al. 2006, Grote et al. 2011), and shifts in the growth strategies of leptocephali 
when they reach large sizes may result in physiological changes (Pfeiler 1999, Bishop et al. 2000). The decrease in percentage of SFAs in larger Serrivomeridae larvae might be caused by 16:0 and 18:0 being used as a major substrates for energy production (Sargent 1995). MUFAs and PUFAs are energy sources for development and growth especially during the larval stage when fish need energy for organogenesis, fast growth and basal metabolism (Abi-ayad et al. 2004, Plante et al. 2006) and these tended to increase in proportion in the leptocephali. Moreover, the PUFA 20:503 is an important energy substrate, as well as the 22:603, which is also one of the principal components of cell membranes (Dalsgaard et al. 2003). In Serrivomeridae, the increase of MUFAs and PUFAs percentages with size suggest that these energetically rich FAs are not preferentially used to provide energy during larval growth. Thus, larvae may be preferentially storing energy dense FAs such as long chain FAs and PUFAs that they cannot synthesize and which are in low concentrations in POM, to support the later highenergy requirements of metamorphosis or to use during the early juvenile stage, when food availability may be uncertain. In bonefish leptocephali, SFA, MUFA, and PUFA FAs were

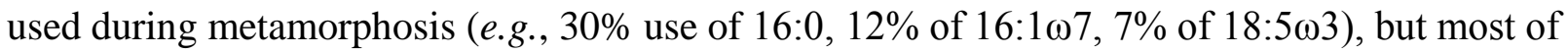
22:603 was conserved (Padrón et al. 1996). More species of leptocephali including those that reach larger sizes than the Serrivomeridae should be examined to further evaluate how FA compositions changes during growth and metamorphosis.

\section{Regional differences in leptocephali and POM}

The isotopic signatures of leptocephali in the 3 current zones showed variations that appeared to be related to the POM signatures in each zone. Both $\delta^{15} \mathrm{~N}$ and $\delta^{13} \mathrm{C}$ values of Nemichthyidae and Muraenidae larvae decreased to some extent from north (SECC) to south (STCC) and the same pattern was seen in POM signatures, especially for $\delta^{15} \mathrm{~N}$. The compositions of the FAs of POM and leptocephali also varied significantly among the current zones. This suggests there is regional variability in the nutritional quality (SFA and 22:603

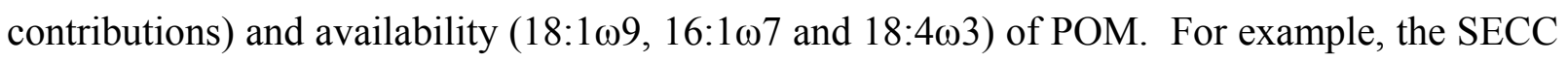
POM had the highest percentage of SFAs and the lowest percentage of MUFAs and PUFAs, which indicates a lower nutritional quality. This may be reflected in the FA compositions of Serrivomeridae larvae that were mostly collected in the SECC, since they also had high SFA contents and low contents of PUFAs compared to the other more widely distributed families. In contrast, the SEC and STCC tended to have POM with higher nutritional quality with larger PUFA and $\omega 3$ contributions. 
These observed differences in POM may have affected the composition of the leptocephali, because many studies indicate that diversity and bioavailability of POM plays a key role in ecosystem functioning by supporting the trophic network (Grémare et al. 1997, Carlier et al. 2007), with regional variability in trophic resources being reflected in the consumers (Cartes et al. 2014, Chouvelon et al. 2014). Our sampling was spread across 20 degrees of latitude and crossed 3 current systems, so it is not surprising that geographic variations were observed in both the SI signatures and FA compositions of POM and leptocephali. This variation was likely due to latitudinal differences in planktonic community structure in the different current systems and temperature regimes, because differences in the $\delta^{15} \mathrm{~N}$ of primary producers can cause variations in the $\delta^{15} \mathrm{~N}$ values of POM and organisms between regions (Somes et al. 2010, Cartes et al. 2014, Lorrain et al. 2015, Soares et al. 2015). Longitudinal differences in the $\delta^{15} \mathrm{~N}$ of mesozooplankton have also been observed around New Caledonia (Hunt et al. 2015).

It is clear though, that questions remain about the feeding ecology of leptocephali, because this study and the study in the western Indian Ocean (Feunteun et al. 2015) have found differences in the compositions of other taxa of leptocephali collected from the same area. Feunteun et al. (2015) found that Nemichthyidae leptocephali had lower $\delta^{15} \mathrm{~N}$ values than Muraenidae and Serrivomeridae leptocephali (and other families), and similar differences were seen between Nemichthyidae and Muraenidae larvae in the STCC zone in the present study. Similar $\delta^{15} \mathrm{~N}$ differences were also seen between Anguilla japonica and Congridae larvae of the genus Ariosoma (Miyazaki et al. 2011) in the western North Pacific. Possible reasons proposed for these differences are similar to those already discussed above, such as different types of POM being selected, the taxa feeding at different depths where the POM is slightly different, differences in assimilation of materials from the POM, or physiological differences among leptocephalus taxa (Miyazaki et al. 2011, Feunteun et al. 2015). To begin to evaluate these possibilities, more research is needed using SI and FA analyses of leptocephali and other food web components in a wider range of areas to gain a better understanding of the feeding ecology of these fish larvae.

Acknowledgements. This project was realized thanks to the help of the captain, crew and technicians of the R/V Hakuo Maru. We also thank the other scientific members for assistance with sampling and plankton sorting. Fatty acid analyses were performed at the French National History Museum of Paris (MNHN-ResAqua), especially with help from Najet Thiney. 
Thanks also to Régis Gallon, Anthony Acou and Emmanuelle Sultan (MNHN, station marine de Dinard), to Christel Lefrançois (University of La Rochelle, LIENs, DYFEA Team), Thierry Wirth (MNHN - EPHE, France) as well as Paco Rodriguez Tress for helping on the project and Dave T. Welsh (Griffith University) for a final editing.

\section{LITERATURE CITED}

Abi-ayad S, Boutiba Z, Melard C, Kestemont P (2004) Dynamics of total body fatty acids during early ontogeny of pikeperch (Sander lucioperca) larvae. Fish Physiol Biochem 30:129-136

Abrantes K, Sheaves M, (2009) Food web structure in a near-pristine mangrove area of the Australian Wet Tropics. Est Coast Shelf Sci 82:597-607

Alldredge AL, Silver MW (1988) Characteristics, dynamics and significance of marine snow. Progr Oceanogr 20:41-82

Bishop RE, Torres JJ, Crabtree RE (2000) Chemical composition and growth indices in leptocephalus larvae. Mar Biol 137:205-214

Böhlke EB (ed) (1989) Leptocephali. Fishes of the Western North Atlantic. Part 9, Vol. 2. Sears Foundation for Marine Research, New Haven.

Boon AR, Duineveld GCA (1996) Phytopigments and fatty acids as molecular markers for the quality of near-bottom particulate organic matter in the North Sea. Neth J Sea Res 35:279291

Budge SM, Iverson SJ, Koopman HN (2006). Studying trophic ecology in marine ecosystems using fatty acids: a primer on analysis and interpretation. Mar Mam Sci 22:759-801

Canuel EA, Cloern JE, Ringelberg DB, Guckert JB, Rau GH (1995) Molecular and isotopic tracers used to examine sources of organic matter and its incorporation into the food webs on San Francisco Bay. Limnol Oceanogr 40:67-81

Carlier A, Riera P, Alouroux JM, Bodiou J-Y, Grémare A (2007) Benthic trophic network in the Bay of Banyuls-sur-Mer (northwest Mediterranean, France): An assessment based on stable carbon and nitrogen isotopes analysis. Est Coast Shelf Sci 72:1-15

Cartes JE, Fanelli E, Kapiris K, Bayhan YK and others (2014) Spatial variability in the trophic ecology and biology of the deep-sea shrimp Aristaeomorpha foliacea in the Mediterranean Sea. Deep-Sea Res 87:1-13 
Castonguay M, McCleave JD (1987) Vertical distributions, diel and ontogenetic vertical migrations and net avoidance of leptocephali of Anguilla and other common species in the Sargasso Sea. J Plankton Res 9:195-214.

Chouvelon T, Chappuis A, Bustamante P, Lefebvre S and others (2014) Trophic ecology of European sardine Sardina pilchardus and European anchovy Engraulis encrasicolus in the Bay of Biscay (north-east Atlantic) inferred from $\delta 13 \mathrm{C}$ and $\delta 15 \mathrm{~N}$ values of fish and identified mesozooplanktonic organisms. J Sea Res 85:277-291

Clarke KR (1993) Non-parametric multivariate analyses of changes in community structure. Aust J Ecol 18:117-143

Clarke KR, Warwick RM (2001) Change in marine communities: An approach to statistical analysis and interpretation. PRIMER-E Ltd, Plymouth Marine Laboratory, UK.

Close HG, Wakeham SG, Pearson A (2014) Lipid and 13C signatures of submicron and suspended particulate organic matter in the Eastern Tropical North Pacific: Implications for the contribution of Bacteria. Deep-Sea Res I 85:15-34

Dalsgaard J, St John M, Kattner G, Muller-Navarra D, Hagen W (2003) Fatty acid trophic markers in the pelagic marine environment. Adv Mar Biol 46:278-340

Deibel D, Parrish CC, Grønkjær PP, Munk P, Gissel Nielsen T (2012) Lipid class and fatty acid content of the leptocephalus larva of tropical eels. Lipids 47:623-634

DeNiro MJ, Epstein S (1978) Influence of diet on the distribution of carbon isotopes in animals. Geochim. Cosmochim Acta 42:495-506

DeNiro MJ, Epstein S (1981) Influence of diet on the distribution of nitrogen isotopes in animals. Geochim. Cosmochim Acta 45:341-351

Dewick PM (1997) The Acetate Pathway: Fatty Acids and Polyketides. In: Medicinal Natural Products: A Biosynthetic Approach. John Wiley \& Sons, New York

Druffel ERM, Griffin S, Bauer JE, Wolgast DM, Wang X-C (1998) Distribution of particulate organic carbon and radiocarbon in the water column from the upper slope to the abyssal NE Pacific Ocean. Deep-Sea Res. II 45:667-687

Druffel ERM, Bauer JE, Griffin S, Hwang J (2003) Penetration of anthropogenic carbon into organic particles of the deep ocean. Geophys Res Lett 30:14

Ederington MC, McManus GB, Harvey HR (1995) Trophic transfer of fatty acids, sterols, and a triterpenoid alcohol between bacteria, a ciliate, and the copepod Acartia tonsa. Limnol Oceanogr 40:860-867 
Engel A, Harlay J, Piontek J, Chou L (2012) Contribution of combined carbohydrates to dissolved and particulate organic carbon after the spring bloom in the northern Bay of Biscay (North-Eastern Atlantic Ocean) Cont Shelf Res 45:42-53

Falk-Petersen S, Hagen W, Kattner G, Clark A, Sargent J (2000) Lipids, trophic relationships, and biodiversity in Arctic and Antarctic krill. Can J Fish Aquat Sci 57:178-191

Feunteun E, Miller MJ, Carpentier A, Aoyama J, and others (2015) Stable isotopic composition of anguilliform leptocephali and other food web components from west of the Mascarene Plateau. Progr Oceanogr

Fry B, Sherr E B (1984) $\delta^{13} \mathrm{C}$ measurements as indicators of carbon flow in marine and freshwater ecosystems. Contrib Mar Sci 27:13-47

Furuita H, Unuma T, Nomura K, Tanaka H, Okuzawa K, Sugita T, Tamamoto T (2006) Lipid and fatty acid composition of eggs producing larvae with high survival rate in the Japanese eel. J Fish Biol 69:1178-1189

Ganachaud A, Cravatte S, Melet A, Schiller A and others (2014) The Southwest Pacific Ocean circulation and climate experiment (SPICE). J Geophys Res Oceans 119:7660-7686

Goericke R, Fry B (1994) Variations of marine plankton $\delta 13 \mathrm{C}$ with latitude, temperature, and dissolved CO2 in the world Ocean. Global Biogeochem Cycle 8:85-90

Govoni JJ (2010) Feeding on protists and particulates by the leptocephali of the worm eels Myrophis spp. (Teleostei: Anguilliformes: Ophichthidae), and the potential energy contribution of large aloricate protozoa. Sci Mar 74:339-344

Grémare A, Amouroux JM, Charles F, Dinet A and others (1997) Temporal changes in the biochemical composition and nutritional value of the particulate organic matter available to surface deposit-feeders: a two year study. Mar Ecol Prog Ser 150:195-206

Grote B, Hagen W, Lipinski MR, Verheye HM, Stenevik EK, Ekau W (2011) Lipids and fatty acids as indicators of egg condition, larval feeding and maternal effects in Cape hakes (Merluccius paradoxus and M. capensis). Mar Biol 158:1005-1017

Hall D, Lee SY, Meziane T (2006) Fatty acids as trophic tracers in an experimental estuarine food chain: tracer transfer. J Exp Mar Biol Ecol 336:42-53

Holloway CF, Cowen JP (1997) Development of a scanning confocal laser microscopic technique to examine the structure and composition of marine snow. Limnol Oceanogr 42:1340-1352 
Hunt BPV, Allain V, Menkes C, Lorrain A and others (2015) A coupled stable isotope-size spectrum approach to understanding pelagic food-web dynamics: A case study from the southwest sub-tropical Pacific. Deep-Sea Res II 113:208-224

Hwang J, Montluçon D, Eglinton TI (2009) Molecular and isotopic constraints on the sources of suspended particulate organic carbon on the northwestern Atlantic margin. Deep-Sea Res I 56:1284-1297

Jeffrey AWA, Pflaum RC, Brooks JM, Sackett WM (1983) Vertical trends in particulate organic carbon 13C:12C ratios in the upper water column. Deep-Sea Res 30:971-983

Kaneda (1991) iso- and anteiso-fatty acids in bacteria: Biosynthesis, function and taxonomic significance. Microbiol Rev 55:288-302

Kattner G, Hagen W, Lee RF, Campbell R and others (2007) Perspectives on marine zooplankton lipids. Can J Fish Aquat Sci 64:1628-1639

Kiørboe T (2000) Colonization of marine snow aggregates by invertebrate zooplankton: abundance, scaling, and possible role. Limnol Oceanogr 45:479-484

Lee RF, Hagen W, Kattner G (2006) Lipid storage in marine zooplankton - a review. Mar Ecol Prog Ser 307:273-306

Lorrain A, Savoye N, Chauvaud L, Paulet Y-M, Naulet N (2003) Decarbonation and preservation method for the analysis of organic $\mathrm{C}$ and $\mathrm{N}$ contents and stable isotope ratios of low-carbonated suspended particulate material. Analyt Chim Acta 491:125-133

Lorrain A, Graham BS, Popp BN, Allain V and others (2015) Nitrogen isotopic baselines and implications for estimating foraging habitat and trophic position of yellowfin tuna in the Indian and Pacific Oceans. Deep-Sea Res 113:188-198

Marui M, Arai T, Miller MJ, Jellyman DJ, Tsukamoto K (2001) Comparison of early life history between New Zealand temperate eels and Pacific tropical eels revealed by otolith microstructure and microchemistry. Mar Ecol Progr Ser 213:273-284

Meziane T, Bodineau L, Retière C, Thoumelin G (1997) The use of lipid markers to examine sources of organic matter and its incorporation into food web of the intertidal salt marshflat ecosystem, Mont Saint Michel Bay, France. J Sea Res 38:47-58

Meziane T, Tsuchiya M (2000) Fatty acids as tracers of organic matter in the sediment and web of a mangrove/intertidal flat ecosystem, Okinawa, Japan. Mar Ecol Prog Ser 200:49-57

Meziane T, Sanabe MC, Tsuchiya M (2002) Role of fiddler crabs of a subtropical intertidal flat on the fate of sedimentary fatty acids. Exp Mar Biol Ecol 270:191-201 
Meziane T, Lee SY, Mfilinge PL, Shin PKS, Lam MHW, Tsuchiya M (2007) Inter-specific and geographical variations in the fatty acid composition of mangrove leaves: implications for using fatty acids as a taxonomic tool and tracers of organic matter. Mar Biol 150:11031113

Miller MJ (2009) Ecology of anguilliform leptocephali: Remarkable transparent fish larvae of the ocean surface layer. Aqua-BioSci Monogr 2(4):1-94

Miller MJ, K Tsukamoto (2004) An introduction to leptocephali: biology and identification. Tokyo: Ocean Research Institute, University of Tokyo, 96 pp

Miller MJ, Aoyama J, Mochioka N, Otake T and others (2006) Geographic variation in the assemblages of leptocephali in the western South Pacific. Deep-Sea Res I 53:776-794

Miller MJ, Otake T, Aoyama J, Wouthuyzen S, Suharti S, Sugeha HY, Tsukamoto K (2011) Observations of gut contents of leptocephali in the North Equatorial Current and Tomini Bay, Indonesia. Coast Mar Sci 35:277-288

Miller MJ, Chikaraishi Y, Ogawa NO, Yamada Y, Tsukamoto K, Ohkouchi N (2013) A low trophic position of Japanese eel larvae indicates feeding on marine snow. Biol Lett 9: 20120826

Minagawa M, Wada E (1984) Stepwise enrichment of $\delta^{15} \mathrm{~N}$ along food chains: Further evidence and the relation between $\delta^{15} \mathrm{~N}$ and animal age. Geochim Cosmochim Acta 48:1135-1140

Miyazaki S, Kim H-Y, Zenimoto K, Kitagawa T, Miller MJ, Kimura S (2011) Stable isotope analysis of two species of anguilliform leptocephali (Anguilla japonica and Ariosoma major) relative to their feeding depth in the North Equatorial Current region. Mar Biol 158:2555-2564

Mochioka N, Iwamizu M (1996) Diet of anguillid larvae: leptocephali feed selectively on larvacean houses and fecal pellets. Mar Biol 125:447-452

Mortillaro JM, Pouilly M, Wach M, Freitas CEC, Abril G, Meziane T (2015) Trophic opportunism of central Amazon floodplain fish. Freshw Biol, Early view. doi: 10.1111/fwb.12598

Mortillaro JM, Abril G, Moreira-Turcq P, Sobrinho RL, Perez M, Meziane T (2011) Fatty acid and stable isotope $(\delta 13 \mathrm{C}, \delta 15 \mathrm{~N})$ signatures of particulate organic matter in the lower Amazon River: Seasonal contrasts and connectivity between floodplain lakes and the mainstem. Organic Geochemistry 42:1159-1168 
Najdek M, Debobbis D, Mioković D, Ivančić I (2002) Fatty acid and phytoplankton compositions of different types of mucilaginous aggregates in thenorthern Adriatic. J Plankt Res 24:424-441

Otake T, Nogami K, Maruyama K (1993) Dissolved and particulate organic matter as possible food sources for eel leptocephali. Mar Ecol Prog Ser 92:27-34

Oksanen J, Blanchet GF, Kindt R, Legendre P, Minchin PR, O'Hara RB, Simpson GL, Solymos P, Henry M, Stevens H, Wagner H (2014) Package 'vegan': Community Ecology Package. Package version 2.2-0

Padrón D, Lindley VA, Pfeiler E (1996) Changes in lipid composition during metamorphosis of bonefish (Albula sp.) leptocephali. Lipids 31:513-519

Passow U (2002) Transparent exopolymer particles (TEP) in aquatic environments. Progr Oceanogr 55:287-333

Peterson BJ, Fry B (1987) Stable isotopes in ecosystem studies. Ann Rev Ecol Syst 18:293320

Pfeiler E (1999) Developmental physiology of elopomorph leptocephali. Comp Biochem Physiol A123:113-128

Pfeiler E, Toyoda H, Williams MD, Nieman RA (2002) Identification, structural analysis and function of hyaluronan in developing fish larvae (leptocephali). Comp Biochem Physiol B 132:443-451

Pitt KA, Connolly M, Meziane T (2009) Stable isotope and fatty acid tracers in energy and nutrient studies of jellyfish: a review. Hydrobiologia 616:119-132

Plante S, Pernet F, Haché R, Ritchie R, Ji B, McIntosh D (2006) Ontogenetic variations in lipid class and fatty acid composition of haddock larvae Melanogrammus aeglefinus in relation to changes in diet and microbial environment. Aquaculture 263:107-121

Popp BN, Laws EA, Bidigare RR, Dore JE, Hanson KL, Wakeham SG (1998) Effect of phytoplankton cell geometry on carbon isotopic fractionation. Geochim Cosmochim Acta 62:69-77

Qiu B, Chen S (2004) Seasonal modulations in the eddy field of the South Pacific Ocean. J Phys Oceanogr 34:1515-1527

Rainuzzo J, Reitan K, Olsen Y (1997) The significance of lipids at early stages of marine fish: a review. Aquaculture 155:103-115

Rau GH, Mearns AJ, Young DR, Olson RJ, Schafer HA, Kaplan IR (1983) Animal ${ }^{13} \mathrm{C} /{ }^{12} \mathrm{C}$ correlates with trophic level in pelagic food webs. Ecology 64:1314-1318 
Riemann L, Alfredsson H, Hansen MM, Als TD and others (2010) Qualitative assessment of the diet of European eel larvae in the Sargasso Sea resolved by DNA barcoding. Biol Lett 6:819-822

Sargent JR, Bell JG, Bell MV, Henderson RJ, Tocher DR (1993) The metabolism of phospholipids and polyunsaturated fatty acids in fish. In: Lahlou B and Vitiello P (eds) Aquaculture: Fundamental and applied research. American Geophysical Union, Washington, DC, p 103-124

Sargent JR (1995). Origin and functions of egg lipids: nutritional implications. In: Bromage, NR, Roberts, RJ (eds), Brood stock Management and Egg and Larval Quality. Blackwell Science, London, pp 353-372

Skoog A, Alldredge A, Passow U, Dunne J, Murray J (2008) Neutral aldoses as source indicators for marine snow. Mar Chem 108:195-206

Scott CL., Kwasniewski S, Falk-Petersen S, Sargent JR (2002) Species differences, origins and functions of fatty alcohols and fatty acids in the wax esters and phospholipids of Calanus hyperboreus, C. glacialis and C. finmarchicus from Arctic waters. Mar Ecol Prog Ser 235:127-134

Schomburg G (1987) Gaschromatographie, second ed. VCH, Weinheim, p 62-72

Shanks AL, Walters K (1997) Holoplankton, meroplankton, and meiofauna associated with marine snow. Mar Ecol Prog Ser 156:75-86

Skerratt JH, Nichols PD, McMeekin TA, Burton H (1995) Seasonal and inter-annual changes in planktonic biomass and community structure in eastern Antarctica using signature lipids. Mar Chem 51:93-113

Somes CJ, Schmittner A, Galbraith ED, Lehmann MF and others (2010) Simulating the global distribution of nitrogen isotopes in the ocean. Global Biogeochem Cycles 24:GB4019

Soares MA, Bhaskar PV, Naik RK, Dessai D, George J, Tiwari M, Anilkumar N (2015) Latitudinal $\delta{ }^{13} \mathrm{C}$ and $\delta{ }^{15} \mathrm{~N}$ variations in particulate organic matter (POM) in surface waters from the Indian ocean sector of Southern Ocean and the Tropical Indian Ocean in 2012. Deep-Sea Res II 11:186-196

Styrishave B, Andersen O (2000) Seasonal variations in hepatopancreas fatty acid profiles of two colour forms of shore crabs, Carcinus maenas. Mar Biol 137:415-422

Tanaka H, Kagawa H, Ohta H, Okuzawa K, Hirose K (1995) The first report of eel larvae ingesting rotifers. Fish Sci 61:171-172 
797

798

799

800

801

802
Waite AM, Muhling BA, Holl CM, Beckley LE and others (2007) Food web structure in two counter-rotating eddies based on $\delta 15 \mathrm{~N}$ and $\delta 13 \mathrm{C}$ isotopic analyses. Deep-Sea Res II 54:1055-1075

Wiegand MD (1996) Composition, accumulation and utilization of yolk lipids in teleost fish. Rev Fish Biol Fish 6:259-286 


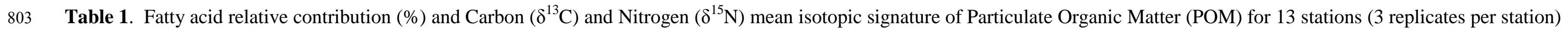
and all leptocephali tissues for the three families Muraenidae (MR), Nemichthyidae (NM) and Serrivomeridae (SR). All values are mean \pm S.D. $n$ is the number of samples.

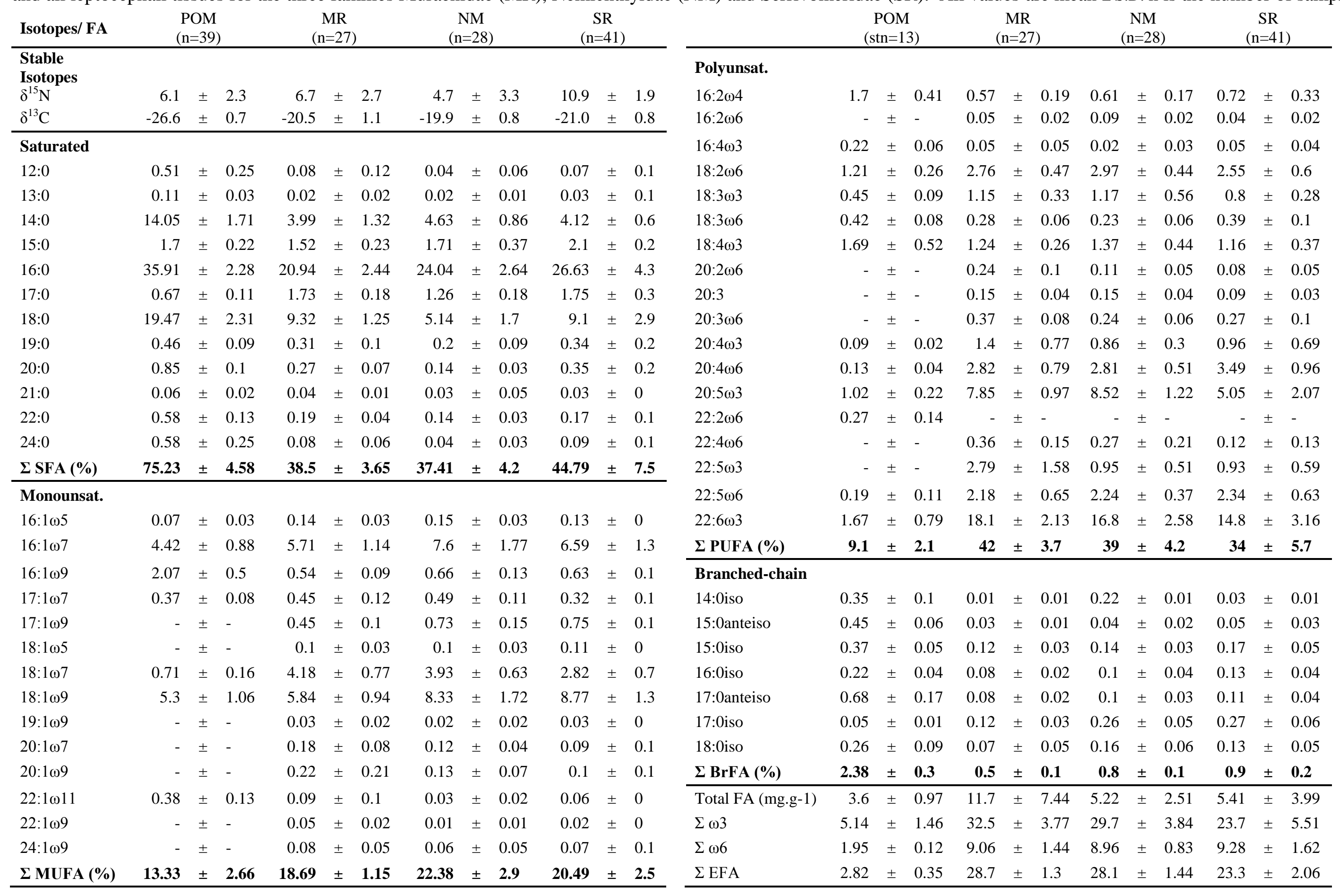




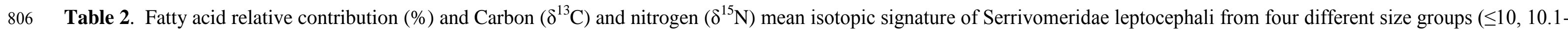

20.0, 20.1-40.0 and 40.1-60.0 mm). The 5 samples of $\leq 10 \mathrm{~mm}$ larvae each include 2 larvae pooled together. All values are mean \pm S.D. $\mathrm{n}$ is the number of samples.

\begin{tabular}{|c|c|c|c|c|c|c|c|c|c|c|c|c|c|c|c|c|c|c|c|c|c|c|c|c|c|}
\hline \multirow{2}{*}{$\begin{array}{l}\text { Stable Isotopes } \\
\delta^{15} \mathrm{~N}\end{array}$} & \multicolumn{3}{|c|}{$\begin{array}{c}\leq 10 \mathrm{~mm} \\
(\mathrm{n}=5)\end{array}$} & \multicolumn{3}{|c|}{$\begin{array}{c}10-20 \mathrm{~mm} \\
(\mathrm{n}=6)\end{array}$} & \multicolumn{3}{|c|}{$\begin{array}{c}20-40 \mathrm{~mm} \\
(\mathrm{n}=20)\end{array}$} & \multicolumn{3}{|c|}{$\begin{array}{c}40-60 \mathrm{~mm} \\
\quad(\mathrm{n}=10)\end{array}$} & \multicolumn{4}{|c|}{$\begin{array}{c}\leq 10 \mathrm{~mm} \\
(\mathrm{n}=5)\end{array}$} & \multicolumn{3}{|c|}{$\begin{array}{c}10-20 \mathrm{~mm} \\
(\mathrm{n}=6)\end{array}$} & \multicolumn{3}{|c|}{$\begin{array}{c}20-40 \mathrm{~mm} \\
\quad(\mathrm{n}=20)\end{array}$} & \multicolumn{3}{|c|}{$\begin{array}{c}40-60 \mathrm{~mm} \\
\quad(\mathrm{n}=10)\end{array}$} \\
\hline & 11.1 & \pm & 1.4 & 11.8 & \pm & 0.8 & 10.6 & \pm & 1.9 & 10.0 & \pm & 2.3 & $16: 2 \omega 4$ & 0.36 & \pm & 0.21 & 0.83 & \pm & 0.39 & 0.68 & \pm & 0.3 & 0.94 & \pm & 0.24 \\
\hline$\delta^{13} \mathrm{C}$ & -19.9 & \pm & 0.57 & -21.3 & \pm & 1.0 & -20.6 & \pm & 0.8 & -21.4 & \pm & 0.5 & $16: 2 \omega 6$ & 0.01 & \pm & 0.01 & 0.04 & \pm & 0.02 & 0.04 & \pm & 0.02 & 0.05 & \pm & 0.03 \\
\hline Saturated & & & & & & & & & & & & & $16: 4 \omega 3$ & 0.05 & \pm & 0.05 & 0.07 & \pm & 0.04 & 0.05 & \pm & 0.04 & 0.03 & \pm & 0.02 \\
\hline 12:0 & 0.13 & \pm & 0.11 & 0.06 & \pm & 0.06 & 0.07 & \pm & 0.05 & 0.04 & \pm & 0.02 & $18: 2 \omega 6$ & 1.93 & \pm & 0.73 & 2.81 & \pm & 0.3 & 2.78 & \pm & 0.26 & 2.25 & \pm & 0.82 \\
\hline 13:0 & 0.05 & \pm & 0.02 & 0.04 & \pm & 0.03 & 0.03 & \pm & 0.01 & 0.03 & \pm & 0.01 & $18: 3 \omega 3$ & 0.48 & \pm & 0.3 & 0.76 & \pm & 0.2 & 0.79 & \pm & 0.26 & 1.1 & \pm & 0.2 \\
\hline 14:0 & 4.5 & \pm & 0.54 & 3.84 & \pm & 0.88 & 3.99 & \pm & 0.55 & 4.35 & \pm & 0.61 & $18: 3 \omega 6$ & 0.32 & \pm & 0.05 & 0.43 & \pm & 0.06 & 0.42 & \pm & 0.1 & 0.37 & \pm & 0.14 \\
\hline $15: 0$ & 2.25 & \pm & 0.29 & 2.07 & \pm & 0.27 & 2.16 & \pm & 0.16 & 1.95 & \pm & 0.12 & $18: 4 \omega 3$ & 0.69 & \pm & 0.41 & 1.17 & \pm & 0.29 & 1.23 & \pm & 0.32 & 1.24 & \pm & 0.34 \\
\hline $16: 0$ & 33.23 & \pm & 5.29 & 27.01 & \pm & 1.33 & 27.22 & \pm & 2.67 & 21.95 & \pm & 1.67 & $20: 2 \omega 6$ & 0.1 & \pm & 0.12 & 0.06 & \pm & 0.02 & 0.07 & \pm & 0.02 & 0.12 & \pm & 0.03 \\
\hline 17:0 & 1.79 & \pm & 0.14 & 1.76 & \pm & 0.24 & 1.83 & \pm & 0.27 & 1.56 & \pm & 0.21 & $20: 3$ & 0.07 & \pm & 0.04 & 0.07 & \pm & 0.02 & 0.09 & \pm & 0.02 & 0.12 & \pm & 0.02 \\
\hline 18:0 & 13.18 & \pm & 3.9 & 9.9 & \pm & 2.25 & 9.17 & \pm & 2.13 & 6.42 & \pm & 0.62 & $20: 3 \omega 6$ & 0.16 & \pm & 0.05 & 0.25 & \pm & 0.05 & 0.25 & \pm & 0.06 & 0.4 & \pm & 0.08 \\
\hline 19:0 & 0.69 & \pm & 0.24 & 0.32 & \pm & 0.14 & 0.3 & \pm & 0.09 & 0.24 & \pm & 0.08 & $20: 4 \omega 3$ & 0.41 & \pm & 0.24 & 0.69 & \pm & 0.22 & 0.67 & \pm & 0.16 & 1.96 & \pm & 0.7 \\
\hline 20:0 & 0.46 & \pm & 0.15 & 0.48 & \pm & 0.39 & 0.31 & \pm & 0.07 & 0.32 & \pm & 0.09 & $20: 4 \omega 6$ & 3.73 & \pm & 1.25 & 3.69 & \pm & 0.77 & 3.89 & \pm & 0.66 & 2.46 & \pm & 0.74 \\
\hline 21:0 & 0.04 & \pm & 0.02 & 0.03 & \pm & 0.01 & 0.04 & \pm & 0.01 & 0.03 & \pm & 0.01 & $20: 5 \omega 3$ & 4.04 & \pm & 1.55 & 5.02 & \pm & 0.69 & 4.47 & \pm & 2.42 & 6.75 & \pm & 0.98 \\
\hline 22:0 & 0.24 & \pm & 0.07 & 0.16 & \pm & 0.03 & 0.17 & \pm & 0.03 & 0.14 & \pm & 0.03 & $22: 4 \omega 6$ & 0.03 & \pm & 0.06 & 0.11 & \pm & 0.11 & 0.09 & \pm & 0.12 & 0.22 & \pm & 0.13 \\
\hline 24:0 & 0.18 & \pm & 0.08 & 0.13 & \pm & 0.11 & 0.07 & \pm & 0.06 & 0.08 & \pm & 0.07 & $22: 5 \omega 3$ & 0.44 & \pm & 0.17 & 0.66 & \pm & 0.1 & 0.77 & \pm & 0.19 & 1.67 & \pm & 0.77 \\
\hline$\Sigma$ SFA $(\%)$ & 56.73 & \pm & 0.91 & 45.79 & \pm & 0.48 & 45.36 & \pm & 0.51 & 37.09 & \pm & 0.3 & $22: 5 \omega 6$ & 2.12 & \pm & 0.68 & 2.36 & \pm & 0.4 & 2.51 & \pm & 0.75 & 2.08 & \pm & 0.3 \\
\hline Monounsat. & & & & & & & & & & & & & $22: 6 \omega 3$ & 10.25 & \pm & 4.35 & 13.54 & \pm & 1.81 & 14.99 & \pm & 2.22 & 17.36 & \pm & 1.95 \\
\hline $16: 1 \omega 5$ & 0.08 & \pm & 0.04 & 0.13 & \pm & 0.02 & 0.14 & \pm & 0.03 & 0.13 & \pm & 0.02 & $\Sigma$ PUFA & 25.17 & \pm & 0.6 & 32.55 & \pm & 0.32 & 33.78 & \pm & 0.47 & 39.01 & \pm & 0.44 \\
\hline $16: 1 \omega 7$ & 4.95 & \pm & 0.81 & 6.54 & \pm & 1.14 & 6.31 & \pm & 0.68 & 8.01 & \pm & 1.24 & Branched-chain & & & & & & & & & & & & \\
\hline $16: 1 \omega 9$ & 0.49 & \pm & 0.14 & 0.63 & \pm & 0.05 & 0.65 & \pm & 0.08 & 0.67 & \pm & 0.06 & 14:0iso & 0.04 & \pm & 0.01 & 0.02 & \pm & 0.01 & 0.03 & \pm & 0.01 & 0.02 & \pm & 0.01 \\
\hline $17: 1 \omega 7$ & 0.3 & \pm & 0.03 & 0.27 & \pm & 0.07 & 0.34 & \pm & 0.1 & 0.33 & \pm & 0.08 & 15:0anteiso & 0.11 & \pm & 0.02 & 0.05 & \pm & 0.02 & 0.05 & \pm & 0.02 & 0.03 & \pm & 0.01 \\
\hline $17: 1 \omega 9$ & 0.6 & \pm & 0.15 & 0.77 & \pm & 0.08 & 0.73 & \pm & 0.11 & 0.84 & \pm & 0.09 & 15:0iso & 0.21 & \pm & 0.07 & 0.15 & \pm & 0.02 & 0.17 & \pm & 0.04 & 0.18 & \pm & 0.04 \\
\hline $18: 1 \omega 5$ & 0.05 & \pm & 0.03 & 0.11 & \pm & 0.01 & 0.11 & \pm & 0.03 & 0.13 & \pm & 0.02 & 16:0iso & 0.17 & \pm & 0.07 & 0.12 & \pm & 0.02 & 0.13 & \pm & 0.04 & 0.14 & \pm & 0.03 \\
\hline $18: 1 \omega 7$ & 2.4 & \pm & 0.3 & 2.77 & \pm & 0.32 & 2.63 & \pm & 0.78 & 3.47 & \pm & 0.38 & 17:0anteiso & 0.15 & \pm & 0.09 & 0.11 & \pm & 0.03 & 0.1 & \pm & 0.02 & 0.08 & \pm & 0.02 \\
\hline $18: 1 \omega 9$ & 7.81 & \pm & 2.11 & 9.33 & \pm & 0.64 & 8.76 & \pm & 1.23 & 8.92 & \pm & 0.94 & 17:0iso & 0.27 & \pm & 0.05 & 0.25 & \pm & 0.04 & 0.27 & \pm & 0.07 & 0.29 & \pm & 0.05 \\
\hline $19: 1 \omega 9$ & 0.02 & \pm & 0.02 & 0.03 & \pm & 0.03 & 0.01 & \pm & 0.02 & 0.06 & \pm & 0.04 & 18:0iso & 0.13 & \pm & 0.05 & 0.12 & \pm & 0.09 & 0.13 & \pm & 0.05 & 0.14 & \pm & 0.03 \\
\hline $20: 1 \omega 7$ & 0.06 & \pm & 0.02 & 0.06 & \pm & 0.03 & 0.07 & \pm & 0.02 & 0.15 & \pm & 0.07 & $\Sigma$ BrFA (\%) & 1.07 & \pm & 0.05 & 0.82 & \pm & 0.03 & 0.88 & \pm & 0.04 & 0.88 & \pm & $\mathbf{0 . 0 3}$ \\
\hline $20: 1 \omega 9$ & 0.07 & \pm & 0.03 & 0.07 & \pm & 0.04 & 0.08 & \pm & 0.03 & 0.19 & \pm & 0.12 & Total FA (mg.g-1) & 5.82 & \pm & 1.08 & 5.19 & \pm & 1.92 & 4.62 & \pm & 1.41 & 4.36 & \pm & 1.54 \\
\hline $22: 1 \omega 11$ & 0.08 & \pm & 0.05 & 0.06 & \pm & 0.03 & 0.06 & \pm & 0.03 & 0.05 & \pm & 0.02 & $\Sigma \omega 3$ & 16.36 & \pm & 1.01 & 21.9 & \pm & 0.48 & 22.97 & \pm & 0.8 & 30.01 & \pm & 0.71 \\
\hline $22: 1 \omega 9$ & 0.02 & \pm & 0.01 & 0.02 & \pm & 0.01 & 0.02 & \pm & 0.02 & 0.02 & \pm & 0.01 & $\Sigma \omega 6$ & 8.39 & \pm & 0.37 & 9.74 & \pm & 0.22 & 10.05 & \pm & 0.25 & 7.95 & \pm & 0.28 \\
\hline $24: 1 \omega 9$ & 0.1 & \pm & 0.03 & 0.05 & \pm & 0.04 & 0.07 & \pm & 0.05 & 0.07 & \pm & 0.07 & $\Sigma$ EFA & 18.02 & \pm & 2.38 & 22.25 & \pm & 1.09 & 23.35 & \pm & 1.77 & 26.57 & \pm & 1.20 \\
\hline
\end{tabular}


809 Table 3: Fatty acid relative contribution (\%) of particulate organic matter (POM) from three different currents (South Equatorial Countercurrent (SECC),

South Equatorial Current (SEC) and Sub-Tropical Countercurrent (STCC). All values are mean \pm S.D. $\mathrm{n}$ is the number of samples.

811

\begin{tabular}{|c|c|c|c|c|c|c|c|c|c|c|c|c|c|c|c|c|c|c|c|}
\hline \multirow[b]{2}{*}{ Stable Isotopes } & \multicolumn{3}{|c|}{$\begin{array}{c}\text { POM in SECC } \\
\quad(\mathrm{n}=15)\end{array}$} & \multicolumn{3}{|c|}{$\begin{array}{c}\text { POM in SEC } \\
(\mathrm{n}=15)\end{array}$} & \multicolumn{3}{|c|}{$\begin{array}{c}\text { POM in STCC } \\
(\mathrm{n}=9)\end{array}$} & & \multicolumn{3}{|c|}{$\begin{array}{c}\text { POM in SECC } \\
\quad(n=15)\end{array}$} & \multicolumn{3}{|c|}{$\begin{array}{c}\text { POM in SEC } \\
(\mathrm{n}=15)\end{array}$} & \multicolumn{3}{|c|}{$\begin{array}{c}\text { POM in STCC } \\
(n=9)\end{array}$} \\
\hline & & & & & & & & & & Polyunsat. & & & & & & & & & \\
\hline$\delta^{15} \mathrm{~N}$ & 7.7 & \pm & 2.3 & 6.1 & \pm & 2.2 & 4.1 & \pm & 1.0 & $16: 2 \omega 4$ & 0.97 & \pm & 0.32 & 1.98 & \pm & 0.4 & 2.45 & \pm & 0.56 \\
\hline$\delta^{13} \mathrm{C}$ & -26.2 & \pm & 0.9 & -26.6 & \pm & 0.5 & -27.0 & \pm & 0.2 & $16: 4 \omega 3$ & 0.26 & \pm & 0.08 & 0.22 & \pm & 0.04 & 0.18 & \pm & 0.07 \\
\hline Saturated FA & & & & & & & & & & $18: 2 \omega 6$ & 1.1 & \pm & 0.21 & 1.24 & \pm & 0.21 & 1.34 & \pm & 0.45 \\
\hline 12:0 & 0.48 & \pm & 0.19 & 0.6 & \pm & 0.32 & 0.41 & \pm & 0.23 & $18: 3 \omega 3$ & 0.44 & \pm & 0.07 & 0.44 & \pm & 0.08 & 0.49 & \pm & 0.14 \\
\hline 13:0 & 0.1 & \pm & 0.03 & 0.13 & \pm & 0.03 & 0.07 & \pm & 0.01 & $18: 3 \omega 6$ & 0.4 & \pm & 0.09 & 0.43 & \pm & 0.07 & 0.42 & \pm & 0.06 \\
\hline 14:0 & 14.05 & \pm & 1.48 & 14.6 & \pm & 1.74 & 13.14 & \pm & 2.03 & $18: 4 \omega 3$ & 1.16 & \pm & 0.24 & 1.93 & \pm & 0.55 & 2.16 & \pm & 0.92 \\
\hline 15:0 & 1.71 & \pm & 0.25 & 1.64 & \pm & 0.25 & 1.8 & \pm & 0.11 & $20: 4 \omega 3$ & 0.09 & \pm & 0.03 & 0.08 & \pm & 0.01 & 0.1 & \pm & 0.03 \\
\hline 16:0 & 37.75 & \pm & 1.9 & 34.87 & \pm & 2.43 & 34.59 & \pm & 2.63 & $20: 4 \omega 6$ & 0.11 & \pm & 0.03 & 0.14 & \pm & 0.05 & 0.16 & \pm & 0.04 \\
\hline 17:0 & 0.74 & \pm & 0.11 & 0.64 & \pm & 0.13 & 0.61 & \pm & 0.06 & $20: 5 \omega 3$ & 0.88 & \pm & 0.21 & 0.9 & \pm & 0.18 & 1.43 & \pm & 0.3 \\
\hline 18:0 & 21.31 & \pm & 2.2 & 18.29 & \pm & 2.56 & 19.53 & \pm & 2.08 & $22: 2 \omega 6$ & 0.31 & \pm & 0.2 & 0.32 & \pm & 0.13 & 0.13 & \pm & 0.05 \\
\hline 19:0 & 0.45 & \pm & 0.08 & 0.42 & \pm & 0.08 & 0.54 & \pm & 0.12 & $22: 5 \omega 6$ & 0.21 & \pm & 0.15 & 0.15 & \pm & 0.08 & 0.21 & \pm & 0.11 \\
\hline 20:0 & 0.94 & \pm & 0.13 & 0.79 & \pm & 0.08 & 0.79 & \pm & 0.08 & $22: 6 \omega 3$ & 1.17 & \pm & 0.51 & 1.71 & \pm & 0.76 & 2.43 & \pm & 1.31 \\
\hline $21: 0$ & 0.06 & \pm & 0.02 & 0.07 & \pm & 0.02 & 0.05 & \pm & 0.02 & $\Sigma$ PUFA (\%) & 7.11 & \pm & 1.44 & 9.53 & \pm & 1.96 & 11.5 & \pm & 3.47 \\
\hline 22:0 & 0.62 & \pm & 0.17 & 0.56 & \pm & 0.11 & 0.55 & \pm & 0.11 & Branched-chain & & & & & & & & & \\
\hline 24:0 & 0.6 & \pm & 0.26 & 0.56 & \pm & 0.2 & 0.59 & \pm & 0.3 & 14:0iso & 0.34 & \pm & 0.12 & 0.35 & \pm & 0.08 & 0.37 & \pm & 0.09 \\
\hline$\Sigma$ SFA $(\%)$ & 78.83 & \pm & 3.86 & 73.16 & \pm & 4 & 72.7 & \pm & 6.72 & 15:0anteiso & 0.46 & \pm & 0.08 & 0.4 & \pm & 0.05 & 0.5 & \pm & 0.06 \\
\hline Monounsat. & & & & & & & & & & 15:0iso & 0.39 & \pm & 0.06 & 0.34 & \pm & 0.04 & 0.37 & \pm & 0.04 \\
\hline $16: 1 \omega 5$ & 0.08 & \pm & 0.04 & 0.08 & \pm & 0.03 & 0.07 & \pm & 0.03 & 16:0iso & 0.21 & \pm & 0.06 & 0.21 & \pm & 0.04 & 0.23 & \pm & 0.02 \\
\hline $16: 1 \omega 7$ & 3.62 & \pm & 0.73 & 5.62 & \pm & 1.1 & 3.76 & \pm & 0.75 & 17:0anteiso & 0.64 & \pm & 0.18 & 0.99 & \pm & 0.26 & 0.23 & \pm & 0.02 \\
\hline $16: 1 \omega 9$ & 1.99 & \pm & 0.49 & 2.2 & \pm & 0.46 & 1.99 & \pm & 0.57 & 17:0iso & 0.06 & \pm & 0.01 & 0.05 & \pm & 0.02 & 0.04 & \pm & 0.01 \\
\hline $17: 1 \omega 7$ & 0.39 & \pm & 0.1 & 0.34 & \pm & 0.04 & 0.37 & \pm & 0.12 & 18:0iso & 0.23 & \pm & 0.09 & 0.28 & \pm & 0.06 & 0.29 & \pm & 0.13 \\
\hline $18: 1 \omega 7$ & 0.65 & \pm & 0.16 & 0.73 & \pm & 0.14 & 0.8 & \pm & 0.2 & $\Sigma$ BrFA (\%) & 2.34 & \pm & 0.46 & 2.62 & \pm & 0.36 & 2.03 & \pm & 0.08 \\
\hline 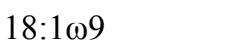 & 4.63 & \pm & 0.91 & 5.32 & \pm & 0.71 & 6.36 & \pm & 1.9 & Total FA (mg.g-1) & 2.86 & \pm & 0.83 & 4.49 & \pm & 0.77 & 3.33 & \pm & 1.53 \\
\hline 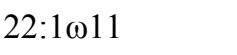 & 0.36 & \pm & 0.11 & 0.39 & \pm & 0.12 & 0.42 & \pm & 0.17 & $\Sigma \omega 3$ & 4.00 & \pm & 0.87 & 5.27 & \pm & 1.49 & 6.81 & \pm & 2.4 \\
\hline$\Sigma$ MUFA (\%) & 11.71 & \pm & 2.87 & 14.68 & \pm & 2.1 & 13.8 & \pm & 3.32 & $\Sigma \omega 6$ & 2.14 & \pm & 0.14 & 2.28 & \pm & 0.11 & 2.26 & \pm & 0.14 \\
\hline & & & & & & & & & & $\Sigma \mathrm{EFA}$ & 2.16 & \pm & 0.25 & 2.75 & \pm & 0.33 & 4.02 & \pm & 0.55 \\
\hline
\end{tabular}




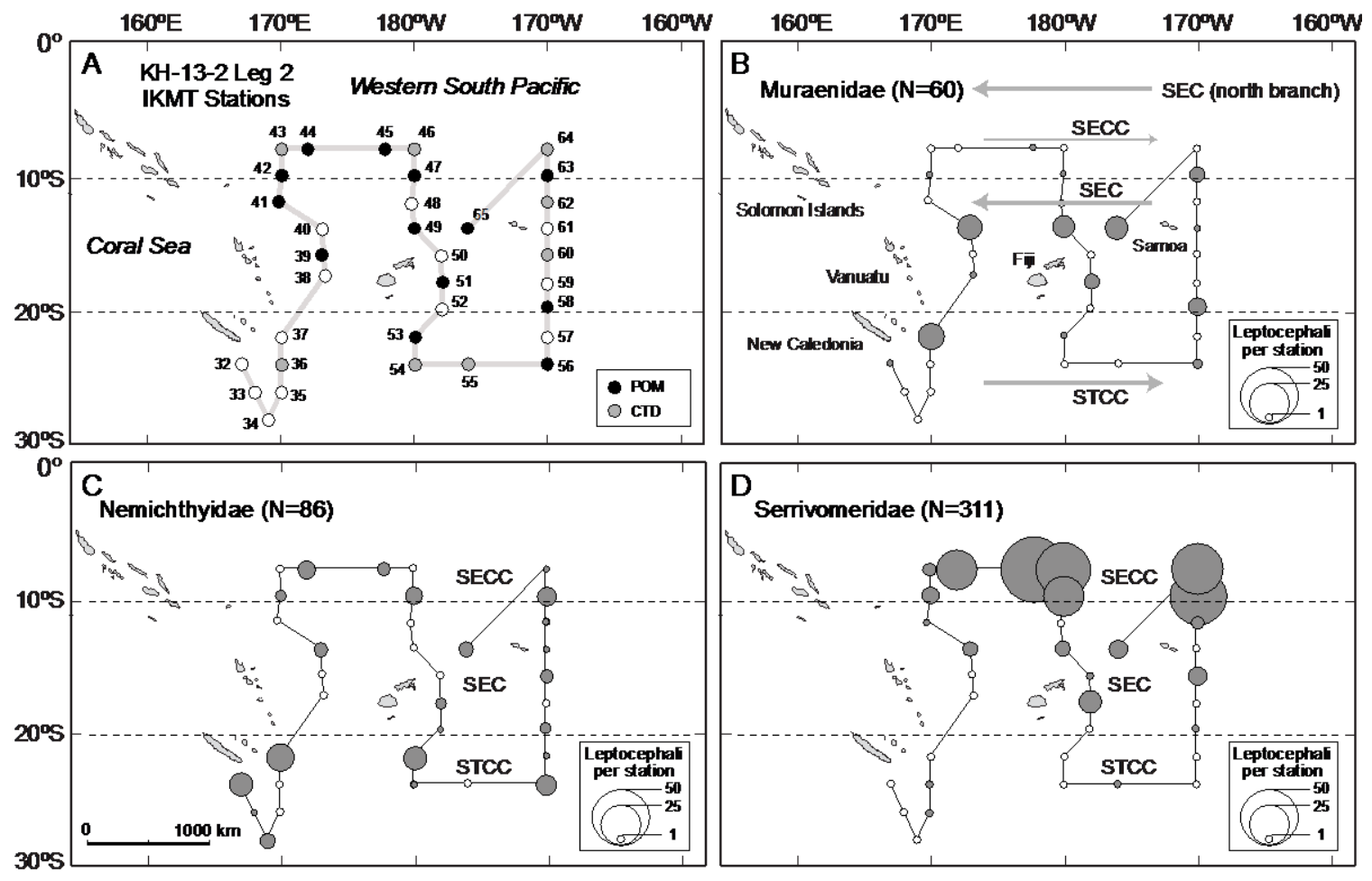

Figure 1: Maps of the KH-13-2 sampling survey of the R/V Hakuho Maru showing (A) the IKMT stations for collecting leptocephali (St. 32-65) and stations where particulate organic matter (POM) was analyzed (black circles) and where other CTD casts were made (shaded circles). The number of leptocephali caught per station of (B) Muraenidae (C) Nemichthyidae, and (D) Serrivomeridae are represented by the relative sizes of the shaded circles. The general locations of the South Equatorial Current (SEC), South Equatorial Countercurrent (SECC) and South Tropical Countercurrent (STCC) are shown with arrows, and the dotted lines separate the 3 current zones used for analyzing latitudinal differences in SI and FA compositions of leptocephali and POM. 


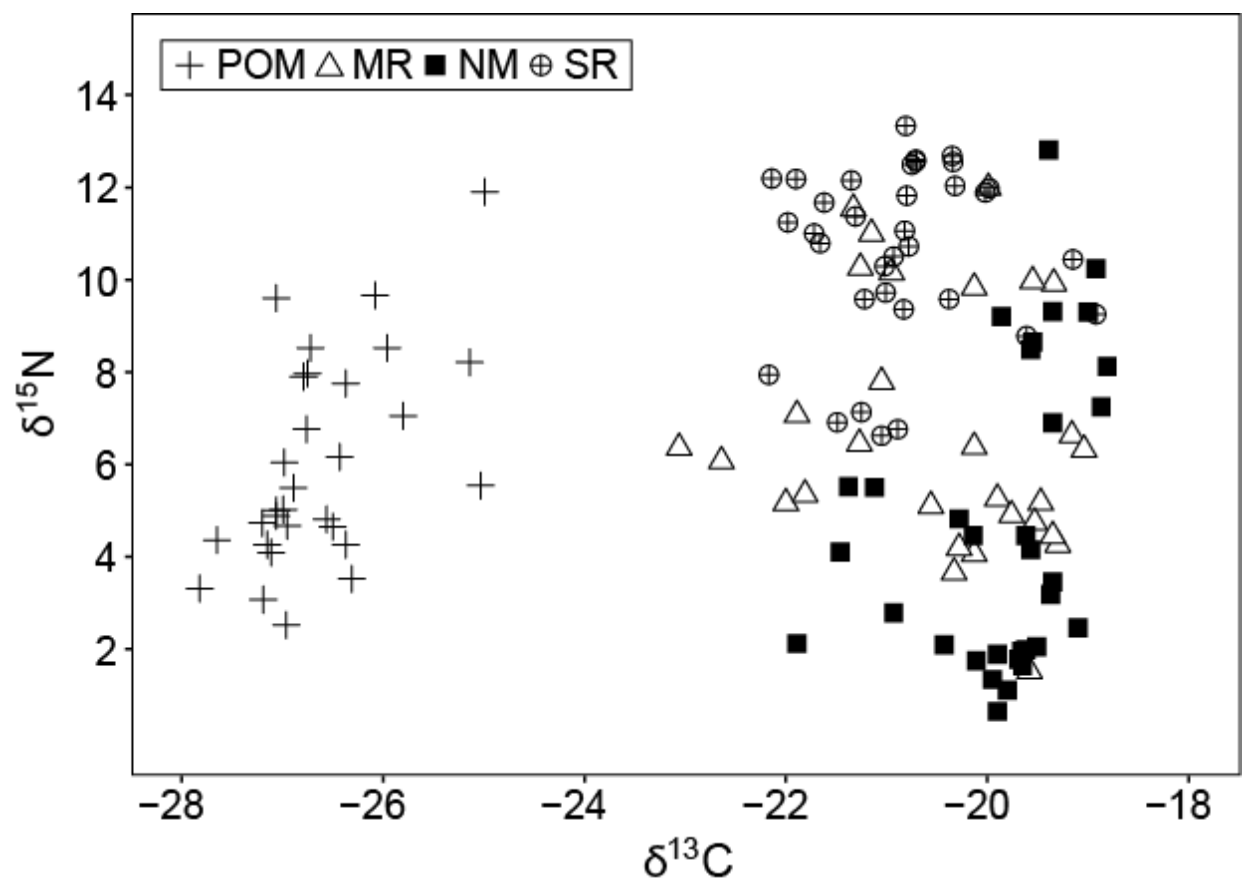

Figure 2. Carbon and nitrogen stable isotope values of particulate organic matter (POM) and the leptocephali of the Muraenidae (MR), Serrivomeridae (SR) and Nemichthyidae (NM). 


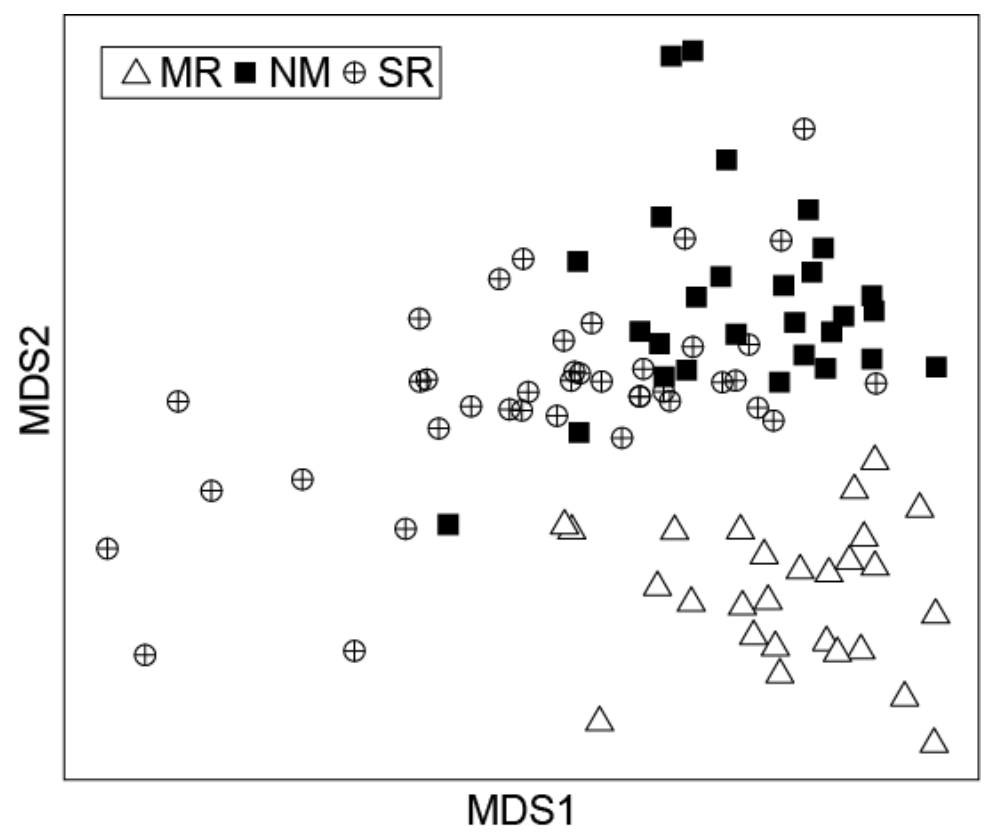

Figure 3. Non-metric multi-dimensional scaling (n-MDS) based on Bray-Curtis similarity distance of total fatty acid composition for leptocephali of the Muraenidae (MR), Serrivomeridae (SR) and Nemichthyidae (NM). Stress $=0.12$. 

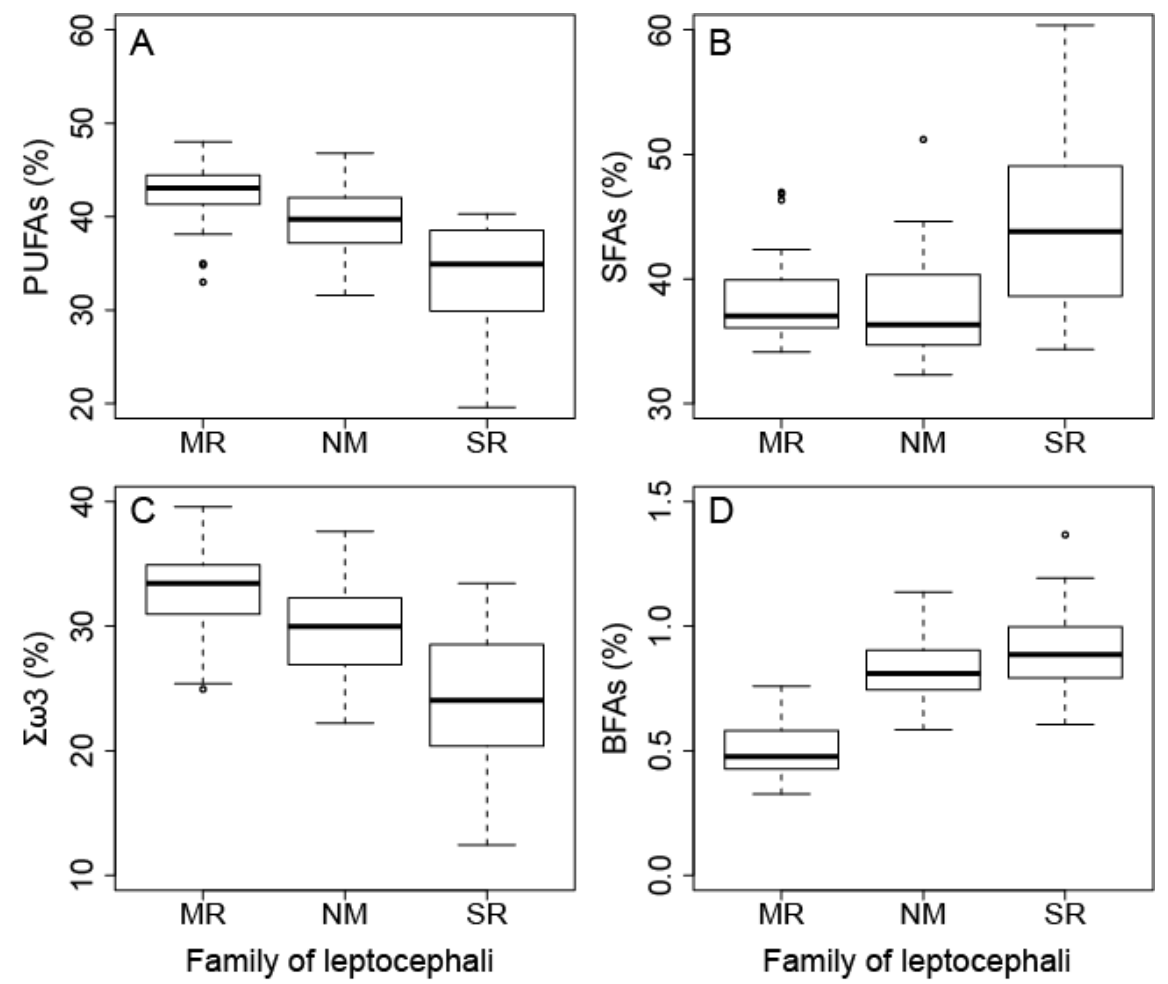

Figure 4. Fatty acids proportions (median, first and third quartiles) of (a) Polyunsatured Fatty Acids (PUFAs), (b) Saturated Fatty Acids (SFAs), (c) sum of $\omega 3$ Fatty Acids ( $\Sigma \omega 3)$, (d) Branched-chain Fatty Acides (BrFAs), for the leptocephali of the Muraenidae (MR), Serrivomeridae (SR) and Nemichthyidae (NM). 


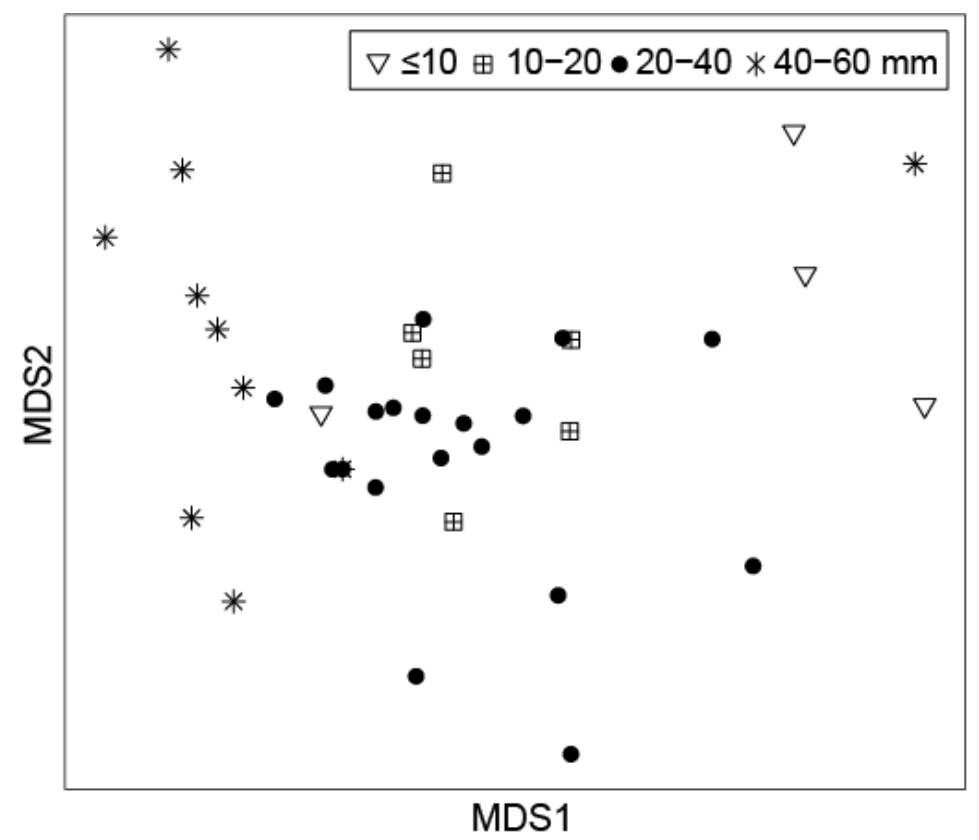

Figure 5. Non-metric MultiDimensional Scaling (n-MDS) based on Bray-Curtis similarity distance of total fatty acid concentration $\left(\mathrm{mg} \mathrm{g}^{-1}\right)$ of Serrivomeridae leptocephali for 4 different size groups (see methods for exact size ranges). Stress $=0.08$. 

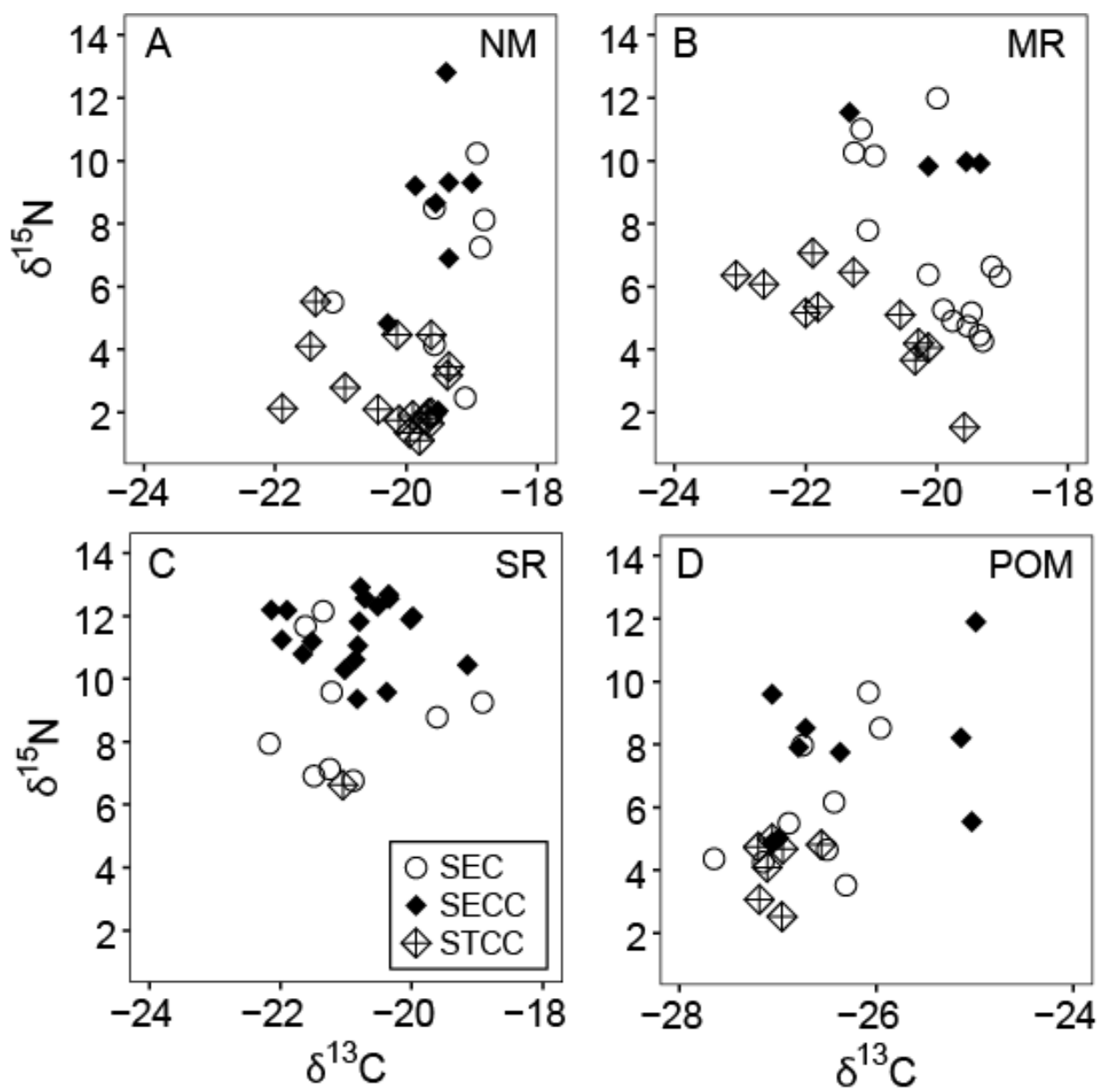

Figure 6. Carbon and nitrogen stable isotope values of (A) Nemichthyidae, (B) Muraenidae, (C) Serrivomeridae leptocephali and (D) POM from the 3 current zones of the South Equatorial Countercurrent (SECC), South Equatorial Current (SEC), and South Tropical Countercurrent (STCC). 